\title{
NOTE
}

\section{RETROACTIVITY AND FIRST AMENDMENT RIGHTS}

The resolution of contemporary problems depends, inevitably, upon past experience; the two cannot and should not be divorced. The proper use of the past is in projection-as an aid to our understanding of the present and our formulation of hopes for the future. A great danger lies in reversing this process-in projecting contemporary problems and attitudes backward in time in an effort to reevaluate past behavior which is susceptible to misinterpretation unless viewed in its original setting. Some distortion of the past may be harmless: does it really matter whether the racoon coat was in fact a staple of the collegiate male wardrobe a generation ago? Indeed, some may be beneficial: our apotheosis of hardheaded politicians of another age as "founding Fathers" may lend a needed inviolability to institutions born of early political compromise. But if the current attitudes which we project back are a product of anxiety or desperation about a real and present threat to our personal and political security, such distortion can be ominous.

In recent years the federal and state governments, alarmed by the international Communist movement, have enacted a number of security and loyalty programs which regulate association and speech. Few will deny that eliminating the internal Communist menace is a desirable end. And, although the dissenters have persisted in challenging many of the means used, a majority of the Supreme Court have held that the Communist Party is, to some extent, constitutionally amenable to control. ${ }^{1}$ They have established that Congress does not offend the first amendment by making conspiracy to advocate violent overthrow of the government-a classic Communist doctrine-a criminal offense. ${ }^{2}$ Nominal membership in the Party, even with knowledge of its aims, is not yet a crime per se, ${ }^{3}$ but it may subject the actor to many disabilities which have been sustained in the face of first amendment challenge. ${ }^{4}$ Thus we have an area in

1 In one of the latest cases in this line of decisions, the Supreme Court last term affirmed an order of the Subversive Activities Control Board requiring the Communist Party to register under $\$ 7$ of the Subversive Activities Control Act, 64 Stat. 993 (1950), as amended, 50 U.S.C. $\$ 786$ (1958). Communist Party v. Subversive Activities Control Bd., 367 U.S. 1 (1961).

2 Dennis v. United States, 341 U.S. 494 (1951). Compare Yates v. United States, 354 U.S. 298 (1957).

3 See Scales v. United States, 367 U.S. 203, 222 (1961) ; cf. Killian v. United States, 82 Sup. Ct. 302, 315 (1961).

4 See Communist Party v. Subversive Activities Control Bd., 367 U.S. 1 (1961); Flemming v. Nestor, 363 U.S. 603 (1960); Galvan v. Press, 347 U.S. 522 (1954); Harisiades v. Shaughnessy, 342 U.S. 580 (1952); Adler v. Board of Educ., 342 
which association and speech may be controlled in consonance with the Constitution. ${ }^{5}$

It is in this exceptional area that most of the retroactive governmental action has come. It is here, where many actions may have seemed constitutionally privileged when they were performed, that the consequences of misunderstanding past action may be gravest. In today's climate of opinion it is easy to forget that in the 1930's the Communist Party was treated in many ways as just another political party ${ }^{6}$ and that Communist activities were judged by the "clear and present danger" test." The change in attitude $^{8}$ is not merely one which contains potential unfairness in attaching

U.S. 485 (1952) ; Gerende v. Board of Supervisors, 341 U.S. 56 (1951) (per curiam); American Communications Ass'n v. Douds, 339 U.S. 382 (1950). See also In re Anastaplo, 366 U.S. 82 (1961) ; Konigsberg v. State Bar, 366 U.S. 36 (1961) ; Nelson v. Los Angeles County, 362 U.S. 1 (1960); Lerner v. Casey, 357 U.S. 468 (1958). Although the substantive question is clearly settled in favor of constitutionality, there are limits, see Yates v. United States, 354 U.S. 298 (1957); Schware v. Board of Bar Examiners, 353 U.S. 232 (1957); Wieman v. Updegraff, 344 U.S. 183 (1952), and the Court has insisted upon procedural fairness and strict statutory construction, see Deutch v. United States, 367 U.S. 456 (1961); Noto v. United States, 367 U.S. 290 (1961) ; Chaunt v. United States, 364 U.S. 350 (1960) ; Speiser v. Randall, 357 U.S. 513, 520 (1958); Bonetti v. Rogers, 356 U.S. 691 (1958); Rowoldt v. Perfetto, 355 U.S. 115 (1957). But see Cafeteria Workers v. McElroy, 367 U.S. 886 (1961). For a recent state case exhibiting strict control over the application of such enactments, see Lowenstein v. Newark Bd. of Educ, 35 N.J. 94, 171 A.2d 265 (1961), reversing a board dismissal of a teacher for refusal to answer questions as to past Party association.

5 Recent cases involving first amendment freedoms in contexts other than the Communist problem indicate that a double standard may be operative. Compare Communist Party v. Subversive Activities Control Bd., 367 U.S. 1 (1961), with Louisiana ex rel. Gremillion v. NAACP, 366 U.S. 293 (1961). Compare Scales v. United States, 367 U.S. 203 (1961), with Shelton v. Tucker, 364 U.S. 479 (1960). See also Torcaso v. Watkins, 367 U.S. 488 (1961) ; Talley v. California, 362 U.S. 60 (1960) ; Bates v. City of Little Rock, 361 U.S. 516 (1960) ; NAACP v. Alabama, 357 U.S. 449 (1958).

6 See Cramp v. Board of Pub. Instruction, 82 Sup. Ct. 275, 280 (1961) ; Schware v. Board of Bar Examiners, 353 U.S. 232, 244 \& n.14 (1957).

7 Schenck v. United States, 249 U.S. 47, 52 (1919); see Herndon v. Lowry, 301 U.S. 242 (1937); Stromberg v. California, 283 U.S. 359 (1931) (by implication); Bridges v. Wixon, 326 U.S. 135, 164-65 (1945) (Murphy, J., concurring); Whitney v. California, 274 U.S. 357, 374 (1927) (Brandeis, J., concurring). See generally Chafee, Free Speech in the United States (1941) (defending); MeiklejohN, Free Speech and Its Relation to Self-Government (1948) (criticizing); Berns, Freedon, VIRTue and the First Amendment 48-72 (1957); Hand, The Binl of RIgHTs 58-61 (1958). Today the test, if not abandoned with respect to the evaluation of the actions of Communists, has at least had the element of immediacy removed. See Dennis v. United States, 341 U.S. 494, 516-17 (1951) (plurality opinion) : "Petitioners intended to overthrow the Government of the United States as speedily as the circumstances would permit. Their conspiracy . . . created a "clear and present danger' of an attempt to overthrow the Government by force and violence." See id. at 542-43 (Frankfurter, J., concurring). Mr. Justice Jackson was of the opinion that the test was not designed for, nor could it properly be applied to, cases such as Demis which required the appraisal of "imponderables." Instead, he "would have saved it, unmodified, for application as a 'rule of reason' in the kind of case for which it was devised . . . [involving] a hot-headed speech on a street corner, or circulation of a few incendiary pamphlets. . " Id. at 568-70 (concurring opinion). Compare Beauharnais v. Illinois, 343 U.S. 250 (1952); American Communications Ass'n v. Douds, 339 U.S. 382 (1950).

8 In contrast to the clear and present danger rationale, language in some of the recent cases involving legislative control of the Communist Party and its members suggests that the legislative judgment is not to be disturbed on such matters-a position very similar to that taken on economic "substantive due process" questions. 
present significance to what may have been innocent conduct. ${ }^{9}$ If current legislation is permitted to disadvantage a past Party member, a precedent is created for the future. The danger lies in our experience with the Communists being such that it may be used by a future generation with different enemies than ours as a precedent for sustaining similar retroactivity ${ }^{10}$ in connection with persons who are engaged in activities which today are considered to be protected by the first amendment.

See Communist Party v. Subversive Activities Control Bd., 367 U.S. 1, $94-95$ (1961) (upholding the registration provisions of the Subversive Activities Control Act of 1950, §7, 64 Stat. 993, as amended, 50 U.S.C. \$786 (1958)):

It is not for the courts to re-examine the validity of these legislative findings and reject them. . . They are the product of extensive investigation by Committees of Congress over more than a decade and a half. Cf. Nebbia v. New York, 291 U.S. 502, 516, 530 [1934]. We certainly cannot dismiss them as unfounded or irrational imaginings. . . And if we accept them, as we must, as a not unentertainable appraisal by Congress of the threat which Communist organizations pose not only to existing government in the United States, but to the United States as a sovereign, independent nationif we accept as not wholly unsupportable the conclusion that those organizations "are not free and independent organizations, but are sections of a world-wide Communist organization and are controlled, directed, and subject to the discipline of the Communist dictatorship of [a] . . . foreign country," $\S 2(5)-$ we must recognize that the power of Congress to regulate Communist organization of that nature is extensive.

Flemming v. Nestor, 363 U.S. 603 (1960), is an even stronger example of such deference. See note 66 infra. On the impropriety of judicial inquiry regarding the motives of legislative committee investigations, see Wilkinson v. United States, 365 U.S. 399, 412 (1961) ; Barenblatt v. United States, 360 U.S. 109, 132-33 (1959).

With this approach compare the thinking of the Court in De Jonge v. Oregon, 299 U.S. 353, 364-65 (1937) :

[Freedom of speech, press, and assembly] may be abused by using speech or press or assembly to incite to violence and crime. The people through their legislatures may protect themselves against that abuse. But the legislative intervention can find constitutional justification only by dealing with the abuse. The rights themselves must not be curtailed. The greater the importance of safeguarding the community from incitements to the overthrow of our institutions by force and violence, the more imperative is the need to preserve inviolate the constitutional rights of free speech, free press and free assembly in order to maintain the opportunity for free political discussion, to the end that government may be responsive to the will of the people and that changes, if desired, may be obtained by peaceful means.

Cf. West Virginia Bd. of Educ. v. Barnette, 319 U.S. 624, 639 (1943) :

The test of legislation which collides with the Fourteenth Amendment, because it also collides with the principles of the First, is much more definite than the test when only the Fourteenth is involved. Much of the vagueness of the due process clause disappears when the specific prohibitions of the First become its standard. The right of a State to regulate, for example, a public utility may well include, so far as the due process test is concerned, power to impose all of the restrictions which a legislature may have a "rational basis" for adopting. But freedoms of speech and of press, of assembly, and of worship may not be infringed on such slender grounds. They are susceptible of restriction only to prevent grave and immediate danger to interests which the state may lawfully protect.

${ }^{\circ}$ Cf. Wieman v. Updegraff, 344 U.S. 183 (1952).

10 Retroactivity is here defined as official action attaching detrimental consequences to conduct occurring prior to the legislation, investigation, or administrative determination. Other definitions of the term are found in Hochman, The Supreme Court and the Constitutionality of Retroactive Legislation, 73 HARv. L. REv. 692 (1960); Slawson, Constitutional and Legislative Considerations in Retroactive Lawmaking, 48 CALIF. L. REv. 216-20 (1960) ; Smith, Retroactive Laze and Vested Rights, 5 TEXAs L. Rev. 231-33 (1927). 
The effect of such action on first amendment freedoms is an issue which has received little judicial attention. This lack of development may be explained in large measure by two factors: first, the Supreme Court has used other grounds to dispose of cases presenting the problem; ${ }^{11}$ and, second, lawmakers have been understandably hesitant to enact such legislation. ${ }^{12}$ This attitude stems from an ancient distrust of retroactivity in any form ${ }^{13}$ and undoubtedly draws some strength from the constitutional mandates against retrospective penal laws-the ex post facto and bill of attainder clauses. ${ }^{14}$ For these reasons, activities on the periphery of the first amendment have not often been the subject of retroactive governmental action. It is not surprising that the few exceptions are almost all in the area of investigation and legislation dealing with Communists and suspected Communists. ${ }^{15}$ In the past, the attitude of the public-assuming an awareness of the problem-towards many of the minority groups involved in first amendment cases has been one of sympathy or indifference. In contrast, few if any Americans have not been exposed to the issue of "Communism"; the threat posed by the international Communist movement is manifest to a very large and diverse audience. The urge to repress has been correspondingly great; and when translated into legislation, ${ }^{16}$ it

11 See, e.g., Flemming v. Nestor, 363 U.S. 603, 613-21 (1960) (reaching the issue of retroactivity but treating it, not in terms of the first amendment, but rather in terms of the ex post facto and bill of attainder clauses); Wieman v. Updegraff, 344 U.S. 183 (1952) (invalidating Oklahoma's loyalty oath legislation for want of a scienter requirement). In a few opinions the Court seems to have had to convince itself, consciously and sometimes with difficulty, that there was no retrospectivity on the facts presented. See Flemming v. Nestor, supra; Harisiades v. Shaughnessy, 342 U.S. 580 (1952) ; Garner v. Board of Pub. Works, 341 U.S. 716 (1951).

12 For example, after the Supreme Court invalidated Oklahoma's loyalty oath, which demanded a disavowal of subversive associations in the five years preceding the taking of the oath, Okla. Laws 1951, tit. 51 , ch. 1, $\$ 11-9$, for lack of an element of scienter, Wieman v. Updegraff, 344 U.S. 183 (1952), the state legislature, although insisting on an oath of some sort for public employees, not only added a requirement of knowing membership, but also gave the oath prospective effect only. See OrIA. Stat. ANN. tit. 51, §\$ 36.1-.6 (Supp. 1960).

13 "The bias against retroactive legislation" was incorporated into the English common law from Roman and Greek sources by Bracton and given currency by Coke as a rule of statutory construction. American courts early adopted it and used it also as a limitation on legislative power. See Smead, The Rule Against Retroactive Legislation: A Basic Principle of Jurisprudence, 20 MINN. L. REv. 775 (1936).

14 U.S. CoNST. art. I, \&9, cl. 3 (limitations on Congress); U.S. CoNsT. art. I, $\$ 10, \mathrm{cl} .1$ (limitations on the states).

15 But see Shelton v. Tucker, 364 U.S. 479 (1960). The deportation laws contain many instances of retroactive operation, some of which deal with aliens other than "subversives" or Communists. E.g., Immigration and Nationality Act of 1952 (McCarran-Walter Act), §241(a) (11), 66 Stat. 204, 8 U.S.C. \$1251(a) (11) (1958); see Mulcahey v. Catalanotte, 353 U.S. 692 (1957); Lehmann v. United States ex rel. Carson, 353 U.S. 685 (1957); Marcello v. Bonds, 349 U.S. 302 (1955).

16 Attacks on the wisdom of legislation exemplifying this attitude have been frequent. See, e.g., Chafee, The Blessings of Liberty $64-252$ (1956); Gellmorn, Anrerican Rights: THE Constitution IN Action 41-131 (1960); O'Brian, Neze Encroachments on Individual Freedom, 66 HARv. L. Rev. 1 (1952). Many pages in the United States Reports also make the point. See, e.g., In re Anastaplo, 366 U.S. 82, 97 (1961) (Black, J., dissenting) ; Speiser v. Randali, 357 U.S. 513, 529 (1958) (Black, J., concurring) ; Beilan v. Board of Educ., 357 U.S. 399, 412 (1958) (Douglas, J., dissenting) ; Dennis v. United States, 341 U.S., 494, 553-56 (1951) (Frankfurter, J., concurring). 'Compare the more conservative ideas in BERNS, op. cit. supra note 7 , at 198-227. 
has been upheld by the courts. ${ }^{17}$ The occurrence of retroactivity in this pattern of legislation and investigation poses special constitutional problems. This Note will attempt to state and evaluate them in terms of the first amendment.

\section{Scope of the Traditional Constitutional Limitations}

At the outset it is important to trace the constitutional limitations on retroactivity which are not likely to afford protection ${ }^{18}$ against the great majority of contemporary statutes which attach current significance to past association or speech. The traditional prohibitions fall into two categories: the ex post facto and bill of attainder provisions, which operate upon criminal or "penal" legislation, and the contract clause ${ }^{19}$ and due process of law requirements of the fifth and fourteenth amendments, which protect "vested" property rights.

\section{A. Limitations on Legislative Punishment-Ex Post Facto and Bill of Attainder}

Some jurists have insisted that the constitutional convention intended the ex post facto clauses to ban all retrospective laws. ${ }^{20}$ Although there is

17 See, e.g., cases collected note 4 supra.

Neither the spirit of liberty nor the spirit of repression is ever totally absent from the American scene. . . The most striking fact in the relation of the history of repressions to the history of judicial review in particular or to the Supreme Court in general is that no direct action by the Court has ever had any significant bearing in either stopping or slowing a repression. .. . The dominant lesson of our history in the relation of the judiciary to repressions is that courts love liberty most when it is under pressure least.

Frank, Revieze and Basic Liberties, in Supreme Court and Supreme Law 113-14 (Cahn ed. 1954). See Bowers, JefFerson AND Hamulton 386-407 (1925) (discussing intolerant judicial action in the Alien and Sedition Act cases); Chafee, Free SpeEch IN THE UNITED STATES 74-79 (1941) (Espionage and Sedition Act cases); cf. Scheiber, The Wilson Administration and Civil Liberties, 1917-1921, at 43 (1960): "The federal Judiciary-termed 'hysterical' by Justice Oliver Wendell Holmes - proved to be highly immoderate in passing on Espionage and Sedition Act cases. Jurymen were reported by one judge to have regarded verdicts of guilty as a means of demonstrating their own loyalty."

18 This is not to say they cannot provide protection. United States v. Lovett, 328 U.S. 303 (1946), Pierce v. Carskadon, 83 U.S. (16 Wall.) 234 (1872), Ex parte Garland, 71 U.S. (4 Wa11.) 333 (1867), and Cummings v. Missouri, 71 U.S. (4 Wall.) 277 (1867), applying the bill of attainder or ex post facto clauses, are exceptions from the past in which retroactive legislation impinging on first amendment rights has been held unconstitutional. The Court in recent years has not been quick to invoke the broad definition of "punishment" provided by Cummings v. Missouri, supra at 320,327 . See, e.g., Flemming v. Nestor, 363 U.S. 603, 612-21 (1960). Compare the Court's unanimous overeagerness to protect property interests in Burgess v. Salmon, 97 U.S. 381 (1878), in which it used the ex post facto clause to invalidate a retroactive application of a tobacco tax increase, when the same result could have been reached by statutory construction.

19 See generally Hale, The Supreme Court and the Contract Clause (pts. 1-3), 57 HARv. L. REv. 512, 621, 852 (1944).

20 For an early view, see the appendix to Mr. Justice Johnson's concurring opinion in Satterlee v. Matthewson, 27 U.S. (2 Pet.) 380, 414, 681 (1829). For a recent view, drawing on contemporary opinion, see Crosskey, The True Meaning of the Constitutional Prohibition of Ex-Post-Facto Laws, 14 U. CHI. L. REv. 539 (1947). 
some history to support this broad reading, the evidence pointing to a narrower view is at least as strong, ${ }^{21}$ and the familiar case of Calder $v$. Bull ${ }^{22}$ interpreted the phrase as applying only to penal laws. ${ }^{23}$ In the language of Mr. Justice Chase:

The prohibition . . . is an additional bulwark in favor of the personal security of the subject, to protect his person from punishment by legislative acts, having a retrospective operation. I do not think it was inserted to secure the citizen in his private rights of either property or contracts. ${ }^{24}$

Although his hornbook dictum outlining the four types of ex post facto laws speaks only of criminal statutes, ${ }^{25}$ the clauses have not been construed so narrowly. ${ }^{28}$ In Cummings v. Missouri ${ }^{27}$ and Ex parte Garland, ${ }^{28}$ the Court, reviewing the Missouri ${ }^{29}$ and federal test oath provisions, ${ }^{30}$ held

21 Compare 2 Farrand, The Records of the Federal Conventron 448-49, 617 (1911), and $3 i d$. at 328 , with $2 i d$. at $375-76,440$, and $3 i d$. at 100 . The Federalist is inconclusive, although it can be read as accommodating the broader interpretation. See 1 The Federalist No. 44, at 307 (Dunne ed. 1901) (Madison).

223 U.S. (3 Dall.) 386 (1798).

23 Id. at 390. Professor Crosskey asserts that the result of the case was influenced by the pressing need for a bankruptcy law, still unenacted in 1798. This fact was brought home to the Court, says Crosskey, by financial embarrassment of one of their colleagues, Mr. Justice Wilson, who found it necessary to be riding circuit in "far-away North Carolina" when Calder was decided. See Crosskey, supra note 20, at 560-63.

243 U.S. ( 3 Dall.) at 390.

25 Ibid.:

I will state what laws I consider ex post facto laws, within the words and the intent of the prohibition. 1st. Every law that makes an action done before the passing of the law, and which was innocent when done, criminal; and punishes such action. 2d. Every law that aggravates a crime, or makes it greater than it was, when committed. 3d. Every law that changes the punishment, and inflicts a greater punishment, than the law annexed to the crime, when committed. 4th. Every law that alters the legal rules of evidence, and receives less, or different testimony, than the law required at the time of the commission of the offence, in order to convict the offender.

${ }^{26}$ Even Mr. Justice Chase did not purport to be exhaustive: "All these, and similar laws, are manifestly unjust and oppressive." Id. at 391. (Emphasis added.)

2771 U.S. (4 Wall.) 277 (1867).

2871 U.S. (4 Wall.) 333 (1867).

29 The Missouri constitution demanded that appointed public officers, lawyers, and clergymen swear that they had not been Confederate sympathizers at any time in the past. Mo. Const. art. II, $\$ \S 3,6,7,14$ (1865). Cummings, a Roman Catholic priest, had been convicted in the Missouri courts of preaching without having taken the oath. Another state statute, West Virginia's requirement that the previously unqualified privilege of nonresident petition to reopen judgment be available only to petitioners who had taken a similar test oath, was laconically voided by the Court in Pierce v. Carskadon, 83 U..S. (16 Wall.) 234 (1872).

30 In 1865 Congress passed a statute requiring lawyers of the federal bar to swear that they had not aided the South nor held any office in Confederate governments. Act of Jan. 24, 1865, ch. 20, 13 Stat. 424. Garland, who had been admitted to practice before the Supreme Court in 1860, had served in the Confederate Senate. Unable to take the new oath, he petitioned to be allowed to continue his federal 
that legislation which is essentially punitive cannot escape the prohibition merely by being cast in civil form. These cases relied not only on the constitutional prohibitions of ex post facto laws, but on the bill of attainder clauses. "They stand for the proposition," said a later Court, "that legislative acts, no matter what their form, that apply either to named individuals or to easily ascertainable members of a group in such a way as to inflict punishment on them without a judicial trial are bills of attainder prohibited by the Constitution." ${ }^{31}$ The test, then, under both the bill of attainder and ex post facto provisions, is whether a noncriminal enactment levies "punishment" in some constitutional sense. ${ }^{32}$ Obviously, this effect will seldom be stamped on the face of a statute; ${ }^{33}$ the court must draw the punitive purpose from legislative history ${ }^{34}$ or, by negative implication, from a lack of any other purpose which a statute might serve. ${ }^{35}$ The search for

practice, asserting that the act was unconstitutional. The statute had enjoyed little success previously in the lower federal courts. See Ex parte Law, 15 Fed. Cas. 3 (No. 8126) (D.C.S.D. Ga. 1866); In re Baxter, 2 Fed. Cas. 1043 (No. 1118) (C.C. E.D. Tenn. 1866); In re Shorter, 22 Fed. Cas. 16 (No. 12811) (D.C.D. Ala. 1865).

31 United States v. Lovett, 328 U.S. 303, 315-16 (1946) (Black, J.).

32 Compare United States v. Lovett, 328 U.S. 303 (1946), with Garner v. Board of Pub. Works, 341 U.S. 716, 722-23 (1951). Compare Cummings v. Missouri, 71 U.S. (4 Wall.) 277 (1867), with Hawker v. New York, 170 U.S. 189 (1898). The concept of "punishment" for bill of attainder purposes is said not to include disabilities imposed because the legislature has ground to believe that past action will give rise to future conduct which it may lawfully proscribe, as contrasted with penalties prescribed directly for past actions. See American Communications Ass'n v. Douds, 339 U.S. 382, 413-14 (1950) (denial of NLRA benefits to unions whose officers failed to submit "noncommunist" affidavits), criticized in Wormuth, Legislative Disqualifications as Bills of Attainder, 4 VAND. L. REv. 603, 615-18 (1951); Comment, The Constitutional Prohibition of Bills of Attainder: $A$ Waning Guaranty of Judicial Trial, 63 YALE L.J. 844, 851-61 (1954). Both commentators stress the lack of judicial determination in identifying the class affected by the Douds-type oath. On this basis they distinguish Hawker v. New York, 170 U.S. 189 (1898), where the Court upheld a disqualification from practicing medicine based on prior judicial conviction of a felony.

33 According to Comment, 63 YALE L.J. 844, 845-46 (1954), the attainder in United States v. Lovett, 328 U.S. 303 (1946), is the sole example in which an American legislature, since the adoption of the Constitution, has gone so far as to name names. The abortive attempt by the House of Representatives to deport Harry Bridges contained all of the necessary elements of a bill of attainder on its face: "[N]otwithstanding any other provision of law the Attorney General . . . is hereby authorized and directed to take into custody forthwith and deport forthwith to Australia, the country of which he is a citizen or subject, the alien, Harry Renton Bridges, whose presence in this country the Congress deems hurtful." H.R. 9766, 76 th Cong., 3d Sess. (1940). The Attorney General, in reply to a request by Senate Committee on Immigration for his opinion on the bill's constitutionality, stated that he thought it unconstitutional. The Committee then suggested an amendment, merely calling for an investigation of Bridges. S. REP. No. 2031, 76th Cong., 3d Sess. (1940).

34 See United States v. Lovett, supra note 33, at 308-13; Cummings v. Missouri, 71 U.S. (4 Wall.) 277 (1867).

35 See Cummings v. Missouri, supra note 34; Pierce v. Carskadon, 83 U.S. (16 Wall.) 234 (1872) (by implication); cf. Trop v. Dulles, 356 U.S. 86, 97 (1958) (plurality opinion). These cases, in which the Court had to go behind the statute, are distinguishable from cases involving enactments which are plainly criminal in form and may be subject to invalidation or attack on ex post facto grounds. See Thompson v. Utah, 170 U.S. 343 (1898); Duncan v. Missouri, 152 U.S. 377 (1894); Hopt v. Utah, 110 U.S. 574 (1884); Gut v. The State, 76 U.S. (9 Wall.) 35 (1870); 
a hidden punitive intent is ticklish judicial business, and the Supreme Court has seldom invalidated "civil" legislation on the basis of finding a legislative design to punish. ${ }^{36}$ Likewise, the Court has seldom been at a loss to discover some legitimate, nonpenal purpose ${ }^{37}$ the constitutionally permissible ends of legislation are numerous, and the mere fact that some person may be disadvantaged, because of his previous conduct, by the operation of a legislative program which might be said to serve one of these ends does not render a statute punitive so as to invoke the ex post facto and bill of attainder prohibitions. ${ }^{38}$

\section{B. Limitations on Legislative Deprivation of Property-The Contract Clause and Due Process of Law}

Constitutional problems have also been generated by legislation which is retroactive only in the sense that it presently takes property that was acquired in the past. This type of nonpenal retroactive legislation has had a checkered history in American law. ${ }^{39}$ Some of the early opinions contain language indicating that statutory impairment of previously vested rights is inherently so unjust as to violate the superconstitutional precepts of natural law. ${ }^{40}$ With the ex post facto avenue closed, ${ }^{41}$ the antagonism to

Wey Him Fong v. United States, 287 F.2d 525 (9th Cir.), cert. denied, 366 U.S. 971 (1961); Chavez v. Dickson, 280 F.2d 727 (9th Cir. 1960); Graham v. Thompson, 246 F.2d 805 (10th Cir. 1957); Mafnas v. Guam, 228 F.2d 283 (9th Cir. 1955); Putty v. United States, 220 F.2d 473 (9th Cir.), cert. denied, 350 U.S. 821 (1955).

36 United States v. Lovett, 328 U.S. 303 (1946), is the only recent example. In the amazing majority opinion in Flemming v. Nestor, 363 U.S. 603 (1960), Mr. Justice Harlan rejected the argument that congressional termination of Social Security benefits to an alien deported as a former Communist revealed a punitive intent. His rebuttal was rested, in part, on the fact that, in supposed contrast, the Court in Cilmmings had a "first-hand acquaintance with ... "the fierce passions" aroused by the Civil War. Id. at 615. This argument implies either that the majority is unaware of similar passions in the last decade-which is admittedly untenable -or that they do not believe this to have been the significant factor in the passage of the statute, which is at least questionable.

37 Two of the rare exceptions are Trop $\nabla$. Dulles, 356 U.S. 86 (1958) (plurality opinion), and Cummings v. Missouri, 71 U.S. (4 Wall.) 277 (1867).

38 Flemming v. Nestor, 363 U.S. 603 (1960); De Veau v. Braisted, 363 U.S. 144 (1960); Barenblatt v. United States, 360 U.S. 109 (1959); Galvan v. Press, 347 U.S. 522 (1954); Hawker v. New York, 170 U.S. 189 (1898); Borrow v. FCC, 285 F.2d 666 (D.C. Cir.), cert. denied, 364 U.S. 892 (1960).

39 The early developments are traced in Smead, supra note 13. Two recent studies are Hochman, supra note 10; Slawson, supra note 10.

40 See Terrett v. Taylor, 13 U.S. (9 Cranch) 43, 50-51, 52 (1815):

We have no knowlèdge of any authority or principle which could support the doctrine, that a legislative grant is revocable in its own nature . . . . Such a doctrine . . is utterly inconsistent with a great and fundamental principle of a republican government, the right of the citizens to the free enjoyment of their property legally acquired. ... [W] think ourselves standing upon the principles of natural justice, upon the fundamental laws of every free government, upon the spirit and the letter of the constitution of the United States, and upon the decisions of most respectable judicial tribunals, in resisting such a doctrine.

See Dash v. Var Kleeck, 7 Johns. R. 477, 501-03 (N.Y. Sup. Ct. 1811).

41 See Calder v. Bull, 3 U.S. (3 Dall.) 386 (1798); notes $22-25$ supra and accompanying text. 
civil retroactivity may have also found expression in the generous reading given the contract clause. ${ }^{42}$ But the early decisions did not condemn all retrospective civil legislation unconditionally; from the outset it was recognized that the public good might sometimes require such enactments ${ }^{43}$ and that some interests affected thereby must bow to the general welfare.44 This recognition exists today, affirmed by modern cases upholding this form of retroactivity when it is necessary to achieve permissible legislative $^{45}$ or administrative ${ }^{46}$ goals. The constitutional area of the lawmakers' competence to alter proprietary interests is limited by the talismanic concept of "vested" property rights; ${ }^{47}$ divestiture of interests which may be so labeled is a deprivation of property without due process of law. ${ }^{48}$ But no invalidating decisions have been placed on this ground in

42 See Trustees of Dartmouth College v. Woodward, 17 U.S. (4 Wheat.) 518 (1819); New Jersey v. Wilson, 11 U.S. (7 Cranch) 164 (1812); Fletcher v. Peck, 10 U.S.' (6 Cranch) 87 (1810). Mr. Justice Johnson complained of this development in his essay on the ex post facto clause appended to his concurring opinion in Satterlee v. Matthewson, 27 U.S. (2 Pet.) 380, 414, 681, 685-86 (1829).

43 See, e.g., Town of Goshen v. Town of Stonington, 4 Conn. 209, 221-22 (1822) ; Boston \& Gunby v. Cummins, $16 \mathrm{Ga} .102,107$ (1854).

44 See, e.g., Wynne's Lesse v. Wynne, 2 Swan. 405; 409-13 (Tenn. 1852).

45 See, e.g., Home Bldg. \& Loan Ass'n v. Blaisdell, 290 U.S. 398 (1934) ; City of Ann Arbor v. Northwest Park Constr. Corp., 280 F.2d 212 (6th Cir. 1960) (zoning ordinances); Battaglia v. General Motors Corp., 169 F.2d 254 (2d Cir.), cert. denied, 335 U.S. 887 (1948) (upholding the constitutionality of the Portal-to-Portal Act of 1947,61 Stat. 84, 29 U.S.C. $\$ \$ 251-62$ (1958)).

46 See, e.g., Addison v. Holly Hill Fruit Prods., Inc., 322 U.S. 607 (1944); Leedom v. International Bhd. of Elec. Workers, 278 F.2d 237 (D.C. Cir. 1960) (upholding NLRB's retroactive application of revised contract bar term).

47 But what kinds of rights are "vested" in this context?

One's first impulse on undertaking to discuss retroactive laws and vested rights is to define a vested right. But when it appears, as soon happens, that this is impossible, one decides to fix the attention upon retroactive laws and leave the matter of definition to follow rather than precede the discussion, assuming for the purpose that a right is vested when it is immune to destruction, and that it is not vested when it is liable to destruction, by retroactive legislation. The simplification of the task which this plan seems to involve, turns out to be something of an illusion, however, when it appears, as also soon happens, that one's preconceived notions of retroactive laws are irreconcilable with the data with which one has to deal.

Smith, supra note 10, at 231.

Supplementing this general doctrine, a number of other formalisms have developed. Thus, a "curative" statute is allowed, United States v. Heinszen \& Co., 206 U.S. 370 (1907); the legislature may alter "remedies" but not "rights," Campbell v. Holt, 115 U.S. 620 (1885); "statutory rights" are subject to divestment, Flanigan v. Sierra County, 196 U.S. 553 (1905) ; "gratuities," Dodge v. Board of Educ., 302 U.S. 74 (1937), and "privileges," Maricopa County v. Valley Nat'l Bank, 318 U.S. 357 (1943), may be withdrawn.

48 See United States v. Bethlehem Steel Corp., 315 U.S. 289 (1942); Lynch v. United States, 292 U.S. 571 (1934) ; Coolidge v. Long, 282 U.S. 582 (1931) ; Untermyer v. Anderson, 276 U.S. 440 (1928); Nichols v. Coolidge, 274 U.S. 531 (1927); Forbes Pioneer Boat Line v. Board of Comm'rs, 258 U.S. 338 (1922); Ochoa v. Hernandez y Morales, 230 U.S. 139 (1913); Ettor v. City of Tacoma, 228 U.S. 148 (1913). 
recent years. ${ }^{48}$ This may be explained by two developments : an increased reliance by governments on achieving change through techniques which call for compensation rather than reliance on the police power, ${ }^{50}$ and the federal judiciary's abdication of "substantive due process" review to defend property rights. ${ }^{51}$ Not surprisingly, the other constitutional sanctuary for vested interests, the contract clause, has also become obsolete. ${ }^{52}$

\section{The Unprotected Area}

The traditional constitutional doctrines attempt to meet two very different needs. The now untended fence around blue-ribbon property interests was designed to preserve the status quo from legislative disruption. In contrast, the ex post facto and bill of attainder clauses have been shaped to ask not what an individual is losing, but why he is losing it.

These safeguards have been judicially defined in terms which do not affect modern retroactive legislation. ${ }^{53}$ Thus, an alien has no absolute right to remain in the country ; ${ }^{54}$ nor has anyone a vested right to a government pension, ${ }^{55}$ a radio license from the $F C C, 56$ primary social security bene-

49 Henkin, Some Reflections on Current Constitutional Controversy, $109 \mathrm{U}$. PA. L. Rev. 637, 640 (1961). But cf. Morey v. Doud, 354 U.S. 457 (1957) (invalidating economic regulation under the equal protection clause).

50 Compare Berman v. Parker, 348 U.S. 26 (1954), with Village of Euclid v. Ambler Realty Co., 272 U.S. 365 (1926).

51 See, e.g., FPC v. Hope Natural Gas Co., 320 U.S. 591 (1944); United States v. Darby, 312 U.S. 100 (1941); Nebbia v. New York, 291 U.S. 502 (1934). The degree of present judicial restraint is indicated by Mr. Justice Murphy's language in Daniel v. Family Security Life Ins. Co., 336 U.S. 220, 224 (1949): "We cannot say that South Carolina is not entitled to call the funeral insurance business an evil. Nor can we say that the statute has no relation to the elimination of those evils. There our inquiry must stop." To the same effect is Williamson v. Lee Optical, Inc., 348 U.S. 483, 487 (1955). See HAND, The BILI OF RIGHTS 43-45 (1958); KaUpeR, FrontIERs of CONSTITUTIONAL LIBERTY 34-37 (1956). The doctrine retains vitality in some state courts. See, e.g., Gambone v. Commonwealth, $375 \mathrm{~Pa}$. 547, $101 \mathrm{~A} .2 \mathrm{~d}$ 634 (1954); Gwynette v. Meyers, 237 S.C. 17, 115 S.E.2d 673 (1960). See generally Hetherington, State Economic Regulation and Substantive Due Process of Law, 53 Nw. U.L. REV. 226 (1958).

52 The Constitution of the United States of America 362 (Corwin ed. 1953). Professor Corwin attributes this decline to two distinct factors: the use of the due process clause in situations where the contract clause might apply, and, more recently, the subordination of contract rights to the police power.

53 It is possible that the two concepts may overlap in some instances. See, e.g., Steinberg v. United States, 163 F. Supp. 590, 592, 594 (Ct. C1. 1958) (Laramore, J., holding 68 Stat. 1142, 5 U.S.C. $\$ 2283$ (a) (1958) unconstitutional on, inter alia, bill of attainder grounds; Whitaker, J., concurring, finding that the statute deprived the plaintiff of a vested right in annuity benefits); In re Shorter, 22 Fed. Cas. 16 (No. 12811) (D.C.D. Ala. 1865). They were both argued (unsuccessfully) in Flemming v. Nestor, 363 U.S. 603 (1960).

54 Harisiades v. Shaughnessy, 342 U.S. 580, 584-88 (1952) ; Fong Yue Ting v. United States, 149 U.S. 698 (1893); Chae Chan Ping v. United States, 130 U.S. 581, 598, 610 (1889) (The Chinese Exclusion Case).

65 Dodge v. Board of Educ., 302 U.S. 74 (1937) ; Rafferty v. United States, 210 F.2d 934 (3d Cir. 1954). But see Steinberg v. United States, 163 F. Supp. 590, 594 (Ct. Cl. 1958) (Whitaker, J., concurring). (1960).

56 See Borrow v. FCC, 285 F.2d 666 (D.C. Cir.), cert. denied, 364 U.S. 892 
fits, ${ }^{57}$ veteran's disability payments, ${ }^{58}$ the practice of a profession, ${ }^{59}$ or public employment ${ }^{60}$-whether it be teaching school ${ }^{61}$ or closing doors on subway trains. ${ }^{62}$ Furthermore, since the current mass of loyalty legislation ${ }^{63}$ and the deportation laws announce themselves not as punishment, but as regulation ${ }^{64}$ or an exercise of "inherent sovereign power," ${ }^{65}$ and since the relevance of past conduct to a valid statutory purpose is usually accepted, ${ }^{66}$ there is little chance of successfully objecting

67 Flemming v. Nestor, 363 U.S. 603, 608-11 (1960) ; Price v. Flemming, 280 F.2d 956 (3d Cir. 1960), cert. denied, 365 U.S. 817 (1961). Compare Stark, Social Security: Its Importance to Lawyers, 43 A.B.A.J. 319 (1957), with Wollenberg, Vested Rights in Social-Security Benefits, 37 ORE. L. REv. 299 (1958).

58 Thompson v. Whittier, 185 F. Supp. 306 (D.D.C. 1960), appeal dismissed, 365 U.S. 465 (1961).

59 In re Anastaplo, 366 U.S. 82 (1961); Konigsberg v. State Bar, 366 U.S. 36 (1961); see Hawker v. New York, 170 U.S. 189 (1898); Dent v. West Virginia, 129 U.S. 114 (1889). But see In the Matter of Schlesinger, $404 \mathrm{~Pa}$ 584, 172 A.2d 835 (1961).

${ }^{60}$ See Garner v. Board of Pub. Works, 341 U.S. 716 (1951) ; Bailey v. Richardson, 182 F.2d 46 (D.C. Cir. 1950), aff'd by an equally divided Contrt, 341 U.S. 918 (1951). Much has been made of Mr. Justice Holmes' aphorism in McAuliffe v. Mayor of New Bedford, 155 Mass. 216, 220, 29 N.E. 517 (1892) : "The petitioner may have a constitutional right to talk politics, but he has no constitutional right to be a policeman." Consider Mr. Justice Douglas' qualification in Barsky v. Board of Regents, 347 U.S. 442, 472-73 (1954) (dissenting opinion): "The dictum of Holmes gives a distortion to the Bill of Rights. It is not an instrument of dispensation but one of deterrents. Certainly a man has no affirmative right to any particular job or skill or occupation. The Bill of Rights does not say who shall be doctors or lawyers or policemen. But it does say that certain rights are protected, that certain things shall not be done. And so the question here is not what government must give, but rather what it may not take away."

61 Adler v. Board of Educ., 342 U.S. 485 (1952) ; see Beilan v. Board of Educ., 357 U.S. 399 (1958).

62 See Lerner v. Casey, 357 U.S. 468 (1958).

63 In 1956 it was found that such programs had already touched one out of every five gainfully employed individuals in the United States. GELIHORN, INDIVIDUAI. Freedom and Governagental Restratnt 105 (1956).

64 See, e.g., Flemming v. Nestor, 363 U.S. 603 (1960), discussed in note 36 supra.

65 See note 81 infra. Many commentators have voiced objection to the Court's deportation-is-not-punishment theme. See, e.g., Boudin, The Settler Within Our Gates: III, 26 N.Y.U.L. REv. 634 (1951); Bullitt, Deportation as a Denial of Substantive Due Process, 28 WASH. L. Rev. 205 (1953); Maslow, Recasting Our Deportation Laz: Proposals for Reform, 56 CoLUM. L. REv. 309 (1956). However, the Supreme Court has consistently stated that it is bound by past decisions holding the ex post facto clause inapplicable. E.g., Harisiades v. Shaughnessy, 342 U.S. 580, 594-95 (1952). In the second part of a carefully developed argument that there are constitutional limits on congressional power to deport the long-term resident alien, Siegfried Hesse demonstrates that the Court is not so precedent-tied on this point as they seem to think. Hesse, The Constitutional Status of the Lazufully Admitted Permanent Resident Alien: The Inherent Limits of the Power To Expel, 69 YALE L.J. 262, 276-90 (1959).

66 The Court is sometimes easily persuaded that a reasonable relation exists. An outstanding recent example is Flemming v. Nestor, 363 U.S. 603 (1960). The question was the constitutionality of terminating petitioner's Social Security benefits because he was deported for past membership in the Communist Party. See notes 212-22 infra and accompanying text. Despite the first amendment implications of the case (efficiently dispatched in a footnote of the majority opinion, 363 U.S. at 613 n.7), the Court foreshadowed the answer to the due process question of reasonableness by stressing that "we must recognize that the Due Process Clause can be thought 
to these disabilities on ex post facto or bill of attainder grounds. ${ }^{67}$

Of course, it cannot be denied that past conduct may have a legitimate bearing on present qualifications. ${ }^{68}$ Few would find it capricious for the medical profession to reject an applicant who has previously performed abortions-even if this standard for disqualification was established after the acts had been done.69 Similarly, the provision of New York's Waterfront Commission Act that no union may collect dues so long as it has a felon among its officers and agents ${ }^{70}$-a harsh rule if it disqualifies an officer whose only criminality is a thirty-three year old conviction for grand larceny ${ }^{71}$-finds ample support in the notorious history of racketeer influence on waterfront hiring. ${ }^{72}$

The relevance of past activity is not conjured away by the first amendment considerations which are raised by the security programs and certain

to interpose a bar only if the statute manifests a patently arbitrary classification, utterly lacking in rational justification." Id. at 611. The relationship advanced by the Court, id. at 612 , speaks for itself:

One benefit which may be thought to accrue to the economy from the Social Security system is the increased over-all national purchasing power resulting from taxation of productive elements of the economy to provide payments to the retired and disabled, who might otherwise be destitute or nearly so, and who would generally spend a comparatively large percentage of their benefit payments. This advantage would be lost as to payments made to one residing abroad. For these purposes, it is, of course, constitutionally irrelevant whether this reasoning in fact underlay the legislative decision, as it is irrelevant that the section does not extend to all to whom the postulated rationale might in logic apply. . . Nor, apart from this, can it be deemed irrational for Congress to have concluded that the public purse should not be utilized to contribute to the support of those deported on the grounds specified in the statute.

For another example of judicial dexterity-although it failed to achieve majority support-see Shelton v. Tucker, 364 U.S. 479, 490 (1960) (Frankfurter, J., dissenting), discussed at notes $232-40$ infra and accompanying text.

67 The Supreme Court has not invalidated a "civil" statute on either of these constitutional grounds since 1946, when it decided United States v. Lovett, 328 U.S. 303 (1946). In the patchwork of opinions fashioned by a majority of the Court in Joint Anti-Fascist Refugee Comm. v. McGrath, 341 U.S. 123 (1951), only Mr. Justice Black, concurring, suggested that the Attorney General's list was a bill of attainder.

68 An uncommonly strict view as to the relevance of the past has recently been taken by the New Jersey Supreme Court in Lowenstein v. Newark Bd. of Educ., 35 N.J. 94, 171 A.2d 265 (1961). In reversing the dismissal of a schoolteacher, the court said: "[Q]uestioning as to past affiliations and activities is not automatically relevant and always permissible, but only so in the event of rational and reasonable doubt of truth of denials as to the present in order to test such statements." Id. at 103,171 A.2d at $269-70$. And the court indicated that it would not let the exception swallow the rule: despite "unorthodox" answers by the teacher and testimony that he had been an active Communist in the 1940 's, the court found "no rational and reasonable doubt of truth of denials as to the present."

${ }^{69}$ Cf. Hawker v. New York, 170 U.S. 189 (1898); Gray v. Connecticut, 159 U.S. 74 (1895); Dent v. West Virginia, 129 U.S. 114 (1889).

70 N.Y. Unconsor. Laws $\$ 9933$ (McKinney 1961). The disability may be removed by pardon or a certificate of good conduct from the parole board. The constitutionality of the act as a whole was sustained in Iinehan v. Waterfront Comm'n, 116 F. Supp. 683 (S.D.N.Y. 1953), aff'd mem., 347 U.S. 439 (1954).

71 See De Veau v. Braisted, 363 U.S. 144 (1960).

72 See id. at 147-50. 
of the deportation provisions; ; $^{73}$ the "keeper of the arsenal" should not be one who once eagerly awaited the Communist millenium, incited streetcorner mobs to riot with his advocacy of violent action, or directed the organization of the Communist Party in the United States. Or, to put a less extreme case, it is tenable to argue, in terms of relevance, that school boards should be able to deny employment to teachers with certain past unsavory associations. ${ }^{74}$

The Supreme Court formulation by which this type of regulatory legislation is judged, the "reasonable relationship" requirement of substantive due process, ${ }^{75}$ accepts the view that past conduct can be given present significance by statute. ${ }^{78}$ Possible encroachment upon first amendment liberties, while perhaps engendering a more diligent review than that given to economic measures, ${ }^{77}$ has not produced any articulated additional test of substance which carries the inquiry beyond relevance; interference with freedoms which is merely incidental to an otherwise valid regulatory scheme is insufficient to void the statute, ${ }^{78}$ and this is so even though the program is concerned with past as well as present speech or association. ${ }^{79}$ It cannot be emphasized too strongly that this "balancing" test is a product

73 See Immigration and Nationality Act of 1952, 66 Stat. 204, 8 U.S.C. $\$ \$ 1251$ (a) (5), (6), (7), (15), (16), (17) (1958); cf. 66 Stat. 183, 240, 261, 8 U.S.C. $\S \S 1182$ (a) (15), (16), (17), 1424, 1451(c) (1958).

74 See Beilan v. Board of Educ., 357 U.S. 399 (1958) ; Adler v. Board of Educ., 342 U.S. 485 (1952); cf. Shelton v. Tucker, 364 U.S. 479 (1960) (holding the Arkansas disclosure-of-association statute unconstitutional):

The question to be decided here is not whether the State of Arkansas can ask certain of its teachers about all their organizational relationships. It is not whether the State can ask all of its teachers about certain of their associational ties. It is not whether teachers can be asked how many organizations they belong to, or how much time they spend in organizational activity. The question is whether the State can ask every one of its teachers to disclose every single organization with which he has been associated over a five-year period.

Id. at 487-88. But see Lowenstein v. Newark Bd. of Educ., 35 N.J. 94, 171 A.2d 265 (1961), discussed in note 68 supra.

75 See, e.g., Nelson v. County of Los Angeles, 362 U.S. 1, 6-8 (1960) ; Barsky v. Board of Regents, 347 U.S. 442, 451-53 (1954); Wieman v. Updegraff, 344 U.S. 183, 190-92 (1952); Ádler v. Board of Educ., 342 U.S. 485, 494-95 (1952); Garner v. Board of Pub. Works, 341 U.S. 716, 720-21 (1951); American Communications Ass'n v. Douds, 339 U.S. 382, 390-93 (1950).

${ }^{30}$ E.g., De Veau v. Braisted, 363 U.S. 144 (1960); Garner v. Board of Pub. Works, 341 U.S. 716 (1951); Hawker v. New York, 170 U.S. 189 (1898).

77 Compare Speiser v. Randall, 357 U.S. 513, 520 (1958): "When we deal with the complex of strands in the web of freedoms which make up free speech, the operation and effect of the method by which speech is sought to be restrained must be subjected to close analysis and critical judgment in the light of the particular circumstances to which it is applied," with Williamson v. Lee Optical, Inc., 348 U.S. 483, 487 (1955): "The Oklahoma law may exact a needless, wasteful requirement in many cases. But it is for the legislature, not the courts, to balance the advantages and disadvantages of the new requirement."

78 American Communications Ass'n v. Douds, 339 U.S. 382, 393-406 (1950).

79 Flemming v. Nestor, 363 U.S. 603 (1960); Galvan v. Press, 347 U.S. 522 (1954); Garner v. Board of Pub. Works, 341 U.S. 716 (1951) ; Borrow v. FCC, 285 F.2d 666 (D.C. Cir.), cert. denied, 364 U.S. 892 (1960); cf. Konigsberg v. State Bar, 366 U.S. 36 (1961); Beilan v. Board of Educ., 357 U.S. 399 (1958). 
of the Communist cases, which, since Dennis $v$. United States, ${ }^{80}$ have consistently expounded a more pliable first amendment than that which has been operative in other association and membership decisions. With regard to deportation, another area in which retroactivity is not uncommon, Congress has long been considered virtually omnipotent. ${ }^{81}$ The exercise of this power does not have to meet even the reasonable relation standard, ${ }^{82}$ the Court being satisfied, except in instances of the most flagrant abuse of power, ${ }^{83}$ to invoke the doctrine of inherent sovereignty.

One is left to inquire whether the feeble restraints on deportation and the fluid due process test, diluted by the questionable presumption of constitutionality, ${ }^{84}$ can be considered to be adequate safeguards in all circum-

80341 U.S. 494 (1951).

81 See the language from Harisiades v. Shaughnessy, 342 U.S. 580, 587-89 (1952), quoted in note 102 infra.

Every sovereign nation has power, inherent in sovereignty and essential to self-preservation, to forbid entrance of foreigners within its dominions, or to admit them only in such cases and upon such conditions as it may see fit to prescribe. Congress may exclude aliens altogether or prescribe terms and conditions upon which they may come into or remain in this country.

Walter, Revising the Lazes Relating to Immigration, Naturalization, and Nationality, H.R. REP. No. 1365, 82d Cong., 2d Sess. 5 (1952) (Immigration and Nationality Act of 1952), paraphrasing Nishimura Ekiu v. United States, 142 U.S. 651, 659 (1892).

In developing his theory that the deportation power is properly a corollary of the exclusion power-regulation of foreign commerce-Hesse traces and critically examines the case law from the beginning, Head Money Cases, 112 U.S. 580 (1884), to the present, Rowoldt v. Perfetto, 355 U.S. 115 (1957). See Hesse, The Constitutional Status of the Lazefully Admitted Permanent Resident Alien: The Pre1917 Cases, 68 YALE L.J. 1578 (1959); Hesse, The Constitutional Status of the Lawefully Admitted Permanent Resident Alien: The Inherent Limits of the Power To Expel, 69 YALE L.J. 262 (1959). He contends that the concept of inherent sovereignty is not firmly embedded in the early decisions, upon which the modern cases rely. See The Pre-1917 Cases, 68 YALE L.J. 1578, 1586-625 (1959). While there are obvious differences between the scope of congressional control over aliens and that which may be exercised by either the federal or state legislatures over citizens, even the deportation cases, as will be developed later, are not inconsistent with the theory that retroactivity has significant first amendment implications.

82 Harisiades v. Shaughnessy, 342 U.S. 580, 584.91 (1952). The argument was not even attempted in Marcello v. Bonds, 349 U.S. 302 (1955), which sustained deportation of an alien on the basis of a 1938 narcotics conviction. However, Mr. Justice Douglas, in dissent, found support for his conclusion that the section violates the ex post facto clause in the absence of any rational connection between the ground for deportation and present fitness to remain in the country. Id. at 321 (dissenting opinion).

83 See Wong Wing v. United States, 163 U.S. 228 (1896).

84 See note 8 supra. There is no doubt that the Court, at least in the Communist cases, has retreated from the view that "the usual presumption supporting legislation is balanced by the preferred place given in our scheme to the great, the indispensable democratic freedoms secured by the First Amendment. . . That priority gives these liberties a sanctity and a sanction not permitting dubious intrusions." Thomas $\mathrm{v}$. Collins, 323 U.S. 516, 529-30 (1945) (Rutledge, J.). See Communist Party v. Subversive Activities Control Bd., 367 U.S. 1 (1961); Flemming v. Nestor, 363 U.S. 603 (1960) ; Barenblatt v. United States, 360 U.S. 109 (1959) ; Beauharnais v. Illinois, 343 U.S. 250 (1952); Dennis v. United States, 341 U.S. 494 (1951); A merican Communications Ass'n v. Douds, 339 U.S. 382 (1950). Some have urged that Congress' failure to give serious consideration to the constitutionality of legislation affords little basis for the presumption. Frank, Review and Basic Liberties, in Supreare CourT AND SUPREMe LAw 109, 122-29 (Cahn ed. 1954); Henkin, supra note 49 , at 637-38. Professor Frank notes that constitutional consideration was vir- 
stances ${ }^{85}$-whether there is a difference in terms of power between permissible prospective regulation of speech and association, and attempts to reach similar conduct retroactively. It is the thesis of this Note that, in certain circumstances, governmental prescription of present disabilities for past conduct should be considered to violate the first amendment.

\section{A Theory of First Amendment Limits}

Short of outright proscription of rights guaranteed by the first amendment, the strongest inhibition to free speech and association is the uncertainty which governmental attempts to effect otherwise legitimate administrative and legislative goals sometimes generate. Though legislators may labor to narrow the restraints imposed by a statute so as to avoid impinging on the exercise of constitutional rights, language, by its very nature, has only limited capacity to direct and inform conduct. ${ }^{86}$ If a statute lies close to the constitutional border between protected and unprotected behavior, some persons are likely to refrain from communications and associations in which they would be protected by the Constitution. When legislative language becomes dangerously imprecise, ${ }^{87}$ when it per-

tually nonexistent in the passage of the Smith Act, 18 U.S.C. $\$ 2385$ (1958), and the non-Communist affidavit provision of the Labor Management Relations Act (Taft-Hartley Act) $\$ 9(\mathrm{~h})$, ch. 120, 61 Stat. 143 (1947) (repealed by 73 Stat. 525 (1959), 29 U.S.C. $\$ 159$ (h) (Supp. II, 1961)); it occurred during debates on the McCarran Act, Internal Security Act of 1950, 64 Stat. 987 (1950), as amended, 50 U.S.C. $\$ \S 781-826$ (1958), but in a formalistic sense only. Frank, stpra at 122-28. And consider the following questions, put by Professors Hart and Wechsler in THE Federal Courts and the FEderal System 93 (1953):

In certain matters courts are content to accept as a basis of decision, without further inquiry, a formally correct determination of the legislative or executive branches. E.g., a statement that a certain statute has in fact been enacted in accordance with the prescribed procedure, or that a certain government is the established government of a country. . . . Why should they not, in all cases, similarly accept the determination of Congress and the President (or in the case of a veto, of a special majority of Congress) that a statute is duly authorized by the Constitution?

Does Congress in voting to enact a bill or the President in approving it actually make or purport to make such a determination? So far at least as concerns questions of the validity of the statute as applied in particular situations, how can they?

Both Congress and the President can obviously contribute to the sound interpretation of the Constitution. But are they, or can they be, so organized and manned as to be able, without aid from the courts, to build up a body of coherent and intelligible constitutional principles, and to carry public conviction that these principles are being observed? In respect of experience and temperament of personnel? Of procedure for decision? Of means of recording grounds of decision? Of opportunity for close examination of particular questions?

85 Many would answer that the Supreme Court's approach is deficient in any circumstance. See, e.g., Gellmorn, American Rights; The Constitution in AcTION (1960); MeIRLEJoHN, FreE Speech aNd Its Relation to Self-Governatent (1948); O'Brian, Neze Encroachments on Individual Freedom, 66 HaRv. L. Rev. 1 (1952).

86 See Frankfurter, Some Reflections on the Reading of Statutes, 47 CoLUM. L. REv. 527, 528-29 (1947); Note, The Void-for-Vagueness Doctrine in the Supreme Court, 109 U. PA. L. REV. 67 (1960).

87 See, e.g., Thornhill v. Alabama, 310 U.S. 88 (1940). 
mits a construction which transgresses the first amendment, 88 the effect of the restraint is more obvious-and more easily corrected. Repeatedly, the Supreme Court has held that statutes which engender "self-imposed restriction [s] on free expression" violate the first amendment. 89

The operation of a retrospective statute raises other problems, because the conduct with which such a statute deals has already taken place. No verbal ambiguity can alter the course of past action which subsequent judicial construction may hold to be covered or not covered by the statute. However, the impact of legislation attaching current significance to past acts cannot be assessed by looking solely to the immediate and direct effects of a particular statute; there are broader consequences for the present and the future when retroactivity in general is permitted. To uphold such a method of dealing with speech and association currently deemed undesirable unavoidably raises questions as to the future impunity of a wide range of communications and affiliations. The effect of vagueness in a prospective statute pales in comparison: not limited to conduct for which, at some future date, disadvantage will be imposed, retroactivity reaches every act that people think might eventually be proscribed. It is no answer to say that all will be well if one adheres to currently acceptable attitudes and patterns of behavior and if one obeys current legislation as to what it is proper to say and with whom it is proper to join. History teaches us otherwise. Society is far too fickle for this precept to furnish a real sense of direction and security.

Today we deal with Communists or suspected Communists. In 1920, instead, the New York Assembly suspended duly elected legislators on the ground that, being Socialists, they were disloyal to the country's principles. In the 1830's the Masons were hunted as outlaws and subversives, and abolitionists were considered revolutionaries of the most dangerous kind in both North and South. Earlier still, at the time of the universally unlamented alien and sedition laws, Thomas Jefferson's party was attacked and its members were derisively called "Jacobins." 80

The most severe manifestation of our anxiety about groups that deviate from accepted attitudes and norms of behavior is some form of official, formal condemnation." Today, this is exemplified by control of "Com-

88 See, e.g., Fowler v. Rhode Island, 345 U.S. 67 (1953).

80 Smith v. California, 361 U.S. 147, 151 (1959); see, e.g., Cramp v. Board of Pub. Instruction, 82 Sup. Ct. 275 (1961); Speiser v. Randall, 357 U.S. 513 (1958).

90 Barenblatt v. United States, 360 U.S. 109, 150-51 (1959) (Black, J., dissenting). (Footnotes omitted.) A more extensive historical review of these and similar efforts to coerce conformity is found in Communist Party v. Subversive Activities Control Bd., 367 U.S. 1, 148-66 (1961) (Black, J., dissenting).

91 Not surprisingly, the cleansing process is most evident during times of intense national emotion and patriotism, such as during and immediately following war. Those who had links with the South were penalized after the Civil War. See Ex parte Garland, 71 U.S. (4 Wall.) 333 (1867); Cummings v. Missouri, 71 U.S. (4 Wall.) 277 (1867) ; Green v. Shumway, 39 N.Y. 418 (1868). The incredible hysteria 
munist-action," "Communist-front," and "Communist-infiltrated" organizations. ${ }^{92}$ Admittedly, in many instances these are deviations of considerable gravity, and outside the storm center other unorthodox segments of the community are still relatively free to operate as they wish, unencumbered by formal disabilities. ${ }^{93}$ Nevertheless, the sanctioning of retrospective as well as prospective legislation endows what is today a limited regulatory program with the power to spawn pervasive and undiscriminating consequences: not only must one avoid associations which are currently subject to governmentally imposed disadvantages, but one should carefully shun those which may lose favor with the next generation.

The danger of upholding legislation directed against past activity is not that preferred freedoms ${ }^{24}$ may be whittled away; it is that they may be nullified. This danger, however, is not inherent in every retroactive statute or regulation. Different circumstances may entail different degrees of inhibition, and sometimes no inhibition at all. To identify the restraints which may have a pervasive impact on constitutionally protected conduct and which, according to the thesis of this Note, ought not to be permitted under the first amendment, it is necessary to compare the status of an act of speech or association at the time it was performed with the disadvantages which are later attached to it by the governmental action in question. This comparison may place the act in one of three broad classes.

(1) Legislation may deny benefits or impose some detriment because of activity which was unencumbered when undertaken..$^{95}$ This is the clearest case of first amendment trangression. To sanction this principle leaves no speech or association of the present fully protected from official reaction to unknown crises in the future.

which swept America during and after World War I was in large part directed at aliens and the foreign-born. See BIDDLE, THE FEAR of FREEDOM 62-67 (1951); SCHEIBER, The Wilson AdMINISTRATION AND CIYIL LIBERTIEs, 1917-1921, at 52-60 (1960). In the early years of World War II, thousands of United States citizens of Japanese descent were rounded up, relocated, and investigated with regard to their loyalty. The Supreme Court upheld the action in Korematsu v. United States, 323 U.S. 214 (1944); Hirabayashi v. United States, 320 U.S. 81 (1943); see GelleoRN, AmericaN Rights: The Constitution IN ACtTon 134-37 (1960); Rostow, The Japanese American Cases-A Disaster, 54 YALE L.J. 489 (1945).

92 See 64 Stat. 989 (1950), as amended, 50 U.S.C. $\$ \$ 782(3)(a),(b),(4),(4 \mathrm{~A})$, (5) (1958). For the general pattern of control, see Internal Security Act of 1950, 64 Stat. 987, as amended, 50 U.S.C. \$\$ 781-857 (1958).

93 Thus, the John Birch Society, though hardly removed from the controversy, is on the "right" side of the storm and thus currently free to indulge a penchant for character assassination as a part of its crusade against Communism.

94 See Hand, The Bill of Rights 50-55 (1958) ; Kauper, Frontiers of ConSTITUTIONAL LIBERTX 37-41 (1956). Mr. Justice Frankfurter criticizes the use of the "preferred position" formula, tracing the case-law development in Kovacs v. Cooper, 336 U.S. 77, 89-97 (1949) (concurring opinion). Although recent cases continue to remind us that first amendment rights deserve special protection, see Torcaso v. Watkins, 367 U.S. 488 (1961), even in the loyalty area, Speiser v. Randall, 357 U.S. 513 (1958) (denial of procedural due process to require taxpayer to take loyalty oath before claiming tax exemption), there is no doubt, as far as the Communist cases are concerned, that they are less preferred today than in the thirties. See note 8 supra.

95 See pp. 428-34 infra. 
(2) Legislation may impose a new detriment for conduct which was subject to some penalty or control when it was undertaken. ${ }^{96}$ The determinative factor should be the extent to which the detriment is increased by the subsequent law, that is, whether the subsequent imposition is of a magnitude sufficiently greater than the old that the prospect of similar accretions would have a general deterrent effect on possibly protected communications and affiliations which are otherwise undeterred by existing legislative controls. If there is no such effect, patterns of conduct will be unaltered, and no first amendment objection can be made beyond that which may be applicable to the original restriction. But if the new retroactive consequences are substantial, such a statute touches two classes which deserve constitutional protection: first, those who, although not actually subject to the comparatively minor extant consequences, may restrict the scope of their action in an attempt to be quite certain that any new and additional disability will not affect them and who, in the process, would forego actions which may be protected by the Constitution; and, second, those who acknowledge that their actions may be within the terms of the current proscription, but who are willing to act anyway and, if challenged, to defend their conduct on the ground that the statute interferes with first amendment activity. ${ }^{97}$ In both situations, pressure is exerted on people to avoid conceivably protected conduct rather than to risk unknown but possibly substantial disadvantages in the future.

(3) Legislation may reestablish or merely restate the significance of past conduct by attaching disadvantages of the same kind as those existing at the time of action. ${ }^{98}$ Although there are some cases involving statutes of this description which afford an opportunity to contend that reinstituting the penalty is so unfair as to violate due process, ${ }^{90}$ the use of this sort of

96 See pp. 426-28 infra.

97 No doubt the "sit-in" demonstrators in the South are in this category. Would their demonstrations against what they believe to be a denial of their constitutional rights have been so well attended if they were threatened not only with light fines and short jail sentences, but with indefinite future consequences, such as loss of all rights to public employment, state pensions, and attendance at state-supported colleges? Compare Garner v. Louisiana ( $82 \mathrm{~S}$. Ct. 248, 263 (1961) (Harlan, J., concurring).

88 See pp. 414-26 infra.

99 To penalize now because of a course of conduct or association long since rejected raises serious questions of fairness. One might say that liberty is curtailed without due process when an individual is denied the right to rescue himself from former wrongs by positive action-action which at the time immunizes him from the then existent disadvantage. Compare text at note 48 supra. An obvious example is that of an alien subject to deportation in 1935 as a member of an organization advocating overthrow of the Government. Had he disassociated himself in 1936, he would have regained nondeportable status, inasmuch as present affiliation was then a requisite to deportation. However, the act of 1940 made past members deportable, thereby including him once again in this category. Despite the harshness of this sequence, the due process argument was rejected in Harisiades v. Shaughnessy, 342 U.S. 580, 584-91 (1952). The contention has not been tested in nondeportation cases, where constitutional restraints on congressional and state power remain-whatever their inadequacies-far more meaningful. Of course, if it is constitutionally unfair in 
retroactivity 100 is unobjectionable when measured by the first amendment. Knowledge that present permissible disabilities may be continued or, if suspended, revived by future legislation should not force the surrender of basic freedoms to any greater extent than do existing controls.

These three categories are of general applicability, regardless of the substance of the statute in question. This is not to say that the details of the official action are irrelevant. The statutory context may disclose information about the possibility of successful challenge on the ground of retroactivity, or it may contain a built-in test which itself can weed out much that is objectionable about inquiry into the past.

Today, governmental action using retrospectivity is generally confined to the areas of deportation, statutory employment qualifications, and legislative investigations. ${ }^{101}$ Some special considerations apply to each.

The history of the deportation laws cautions us not to expect too much from the judiciary when it is faced with retroactive legislation in this area. Although many of the cases evoke our sympathies ${ }^{102}$ and although recently the Court, perhaps similarly affected, has labored to construe the statutes so as to arrive at some surprising but decent results, ${ }^{103}$

cases of revitalization of penalties, the due process assertion has equal or more persuasive application in instances of increase of penalty or imposition of detriment on previously uncontrolled activity. Cf. Schware v. Board of Bar Examiners, 353 U.S. 232, 244-47 (1957).

100 A statute which reinstates a former disadvantage may be described as not retroactive at all. Mr. Justice Jackson so held in writing for the majority in Harisiades v. Shaughnessy, 342 U.S. 580, 593-94 (1952) (alternative holding), discussed in text accompanying notes 113-21 infra; cf. Garner v. Board of Pub. Works, 341 U.S. 716 (1951).

101 Another area where governmental retrospectivity may be a problem is that of legislated annuities and pensions. Note the retroactivity permitted by the statutes considered in: Flemming v. Nestor, 363 U.S. 603 (1960) (Social Security), discussed in note 66 supra; Thompson v. Whittier, 185 F. Supp. 306 (D.D.C. 1960), appeal dismissed, 365 U.S. 465 (1961) (forfeiture of benefits by anyone shown to the satisfaction of the Veterans Administrator to be guilty of, inter alia, rendering assistance to an enemy of the United States); Steinberg v. United States, 163 F. Supp 590 (Ct. Cl. 1958) (retirement annuity not to be paid to anyone who has pleaded the fifth amendment before a federal grand jury, court, or congressional committee). This type of legislation may be distinguished by the apparent lack of regulatory purpose in the subsequent disabilities. This being so, provisions which make acts prior to the statute a bar to payments otherwise due fall dangerously close to the prohibitions of the ex post facto and bill of attainder clauses. See Steinberg v. United States, supra. But regardless of whether these constitutional protections are available, it is clear that insofar as the rights of speech and association are concerned, such laws are potential weapons of abuse and should be subject to first amendment limitations.

102 Indeed, the Court has offered its sympathy in some of these cases. See Harisiades v. Shaughnessy, 342 U.S. 580, 587-88 (1952), where the Court, affirming action to enforce the statute, said: "That aliens remain vulnerable to expulsion after long residence is a practice that bristles with severities. But it is a weapon of defense and reprisal confirmed by international law as a power inherent in every sovereign state. Such is the traditional power of the Nation over the alien and we leave the law on the subject as we find it." (Footnote omitted.) See also Jay v. Boyd, 351 U.S. 345, 357 (1956); In the Matter of Noland, 185 F. Supp. 948 (D. Neb. 1960). 103 See Bonetti v. Rogers, 356 U.S. 691 (1958) ; Rowoldt v. Perfetto, 355 U.S. 115 (1957); United States v. Witkovich, 353 U.S. 194 (1957); cf. Chaunt v. United States, 364 U.S. 350 (1960) (denaturalization); Maisenberg v. United States, 356 U.S. 670 (1958) (same); Nowak v. United States, 356 U.S. 660 (1958) (same). 
the rule seems to be that the deportation provisions are not bridled by the Constitution. ${ }^{104}$ Decisions like Rowoldt v. Perfetto, ${ }^{105}$ straining to read the statutory provision as inapplicable to a past nominal member of the Party, suggest that a breakthrough at the constitutional level may be in the offing. Meanwhile, it is wishful thinking to expect resort to the first amendment to save past innocent association from becoming grounds for present deportation, should Congress so legislate.

In contrast, the existing constitutional standard of relevance enunciated in the employment and professional qualification cases could, if strictly applied, eliminate virtually all of the retroactive legislation presenting first amendment problems in this field. To achieve this, several factors would have to be carefully weighed in each case: the nature of the past conduct, the length of time which has passed since the activity, the official position regarding such action at the time it was undertaken, and the difference, if any, between the community's opinion of the conduct then and now. If past association or speech can be deemed relevant when viewed in the light of these considerations, the danger of creating a precedent for restraints which threaten the future exercise of first amendment freedoms will be minimal. ${ }^{106}$

The relevance test is not so helpful in the investigative context, where legislators, of necessity, must review past conduct as a guide for the preparation of future laws. The great breadth of the typical legislative inquiry will permit questions which overreach the lines drawn by this Note, although diligent judicial supervision of the committees, to see that they do not violate their authority or the announced scope of investigation, ${ }^{107}$ may help to reduce the frequency of such questions.

\section{The Case Law}

Concern about past speech and association made retroactively illegal is raised perhaps more by waves of security-prompted legislative investigations than by specific enactments imposing disabilities for once-legal conduct. Investigations which delve without apparent restraint into the pasts of those who are brought before legislative committees may lead both laymen and lawyers to conclude generally that statutes which do the same thing are permissible. In addition, language by some of the Justices in recent Supreme Court decisions suggests that the relevance-a narrow inquiry under the fifth and fourteenth amendments-of remote conduct to present regulatory interests is the major criterion by which the validity of governmental action retrospectively attaching significance to that conduct is to be

104 See notes 65,81 supra.

105355 U.S. 115 (1957), discussed in text accompanying notes 133-39 infra.

106 For an example, see the use of the relevance requirement made by the Supreme Court of New Jersey in overturning the dismissal of a teacher in Lowenstein v. Newark Bd. of Educ., 35 N.J. 94, 171 A.2d 265 (1961).

107 See Deutch v. United States, 367 U.S. 456 (1961) ; Sweezy v. New Hampshire, 354 U.S. 234 (1957) ; United States v. Rumely, 345 U.S. 41 (1953). 
judged. ${ }^{108}$ Yet it is not too late to espouse a theory that statutes which stigmatize speech and association retroactively may be invalid even though the same activities might be prospectively prohibited. While the Supreme Court has not acknowledged this thesis, it has, for whatever reasons, acted consistently with it. In no case in this sensitive area has the Court upheld a statute which imposed retroactively a significant and unforeseeable disability in the form of a job or professional disqualification, a withdrawal of statutory benefits, or even deportation. At the same time, it must be acknowledged that no statute has been struck down specifically because of its retrospective effect on freedom of expression or affiliation. ${ }^{109}$ Rather, due process of law under the fifth and fourteenth amendments has provided the basis for the invalidation of those enactments which, according to the thesis of this Note, have offended the first amendment in their retrospectivity. ${ }^{110}$

To admit that avoidance of retroactive repression of freedoms of speech and association has not been an articulated rationale for the decisions is not to deny that a pattern of avoidance exists. The case has not arisen in which naked retroactivity in the first amendment area has had to be the sole determinant of invalidity, but in the decisions made and those carefully not made the Court has gone to considerable lengths to ensure that the statutes it has upheld have not condemned previously innocent speech or association retroactively. In the main, whether or not this line has already been drawn, there are strong indications that it will not be crossed.

\section{A. Statutes Which Revitalize Penalties}

\section{Deportation}

It is appropriate to begin a discussion of statutes which seem to be unlimited in their retrospective operation with deportation, the area most clearly established to be outside the specific constitutional restraints on retroactive legislation. The Alien Registration Act of $1940^{111}$ made former membership in an organization which advocates violent or forcible overthrow of the government a ground for deportation; prior law had rendered an alien deportable only while he was a member of such an organization. ${ }^{112}$ In Harisiades $v$. Shanghnessy, ${ }^{113}$ the Court upheld application of the new ground to aliens who had left the Communist Party

108 See Konigsberg v. State Bar, 366 U.S. 36, 52 (1961) ; Garner v. Board of Pub. Works, 341 U.S. 716, 720 (1951); Adler v. Board of Educ., 342 U.S. 485, 493 (1952) (dictum); cf. Barenblatt v. United States, 360 U.S. 109, 126 (1959). The nature of the disability effected by the governmental action may also be considered. See Konigsberg v. State Bar, supra at 52-53; text accompanying notes 238-41 infra. 109 But see Wieman v. Updegraff, 344 U.S. 183, 193 (1952) (Black, J., concurring).

110 E.g., Wieman v. Updegraff, supra note 109, at 191.

111 Ch. 439, § 23, 54 Stat. 673.

112 Act of Oct. 16, 1918, ch. 186, §2, 40 Stat. 1012, Kessler v. Strecker, 307 U.S. 22 (1939).

113342 U.S. 580 (1952). 
before 1940. (The trial court had found that the Party advocated violent and forcible overthrow of the United States during the period of the aliens' membership.) Petitioners challenged anew the old doctrines that admission for permanent residence confers on an alien no vested right to remain in the country, ${ }^{114}$ that ex post facto applies only to criminal sanctions, ${ }^{115}$ and that deportation is not punishment. ${ }^{116}$ With two Justices in dissent, ${ }^{117}$ the Court refused to overrule these precedents. ${ }^{118}$ Significantly, however, the Court disposed of the challenge on ex post facto grounds by concluding alternatively that the operation of the law was not, in fact, retroactive: membership in any organization advocating overthrow of the Government by force or violence had been a ground for deportation ever since 1920.119 Mr. Justice Jackson, for the majority, pointed out that these aliens "were not caught unawares by a change of law. There can be no contention that they were not adequately forewarned both that their conduct was prohibited and of its consequences." 120

This conclusion, together with an observation that the Communist Party had repeatedly been held to be one of the proscribed organizations, ${ }^{121}$ avoided much of the objection to retroactivity in the 1940 act. It also foreshadowed the result in Galvan v. Press. ${ }^{122}$ In that case, the Court sustained deportation of former members under the Internal Security Act of 1950,123 which dispensed with the need to prove in each case that the Communist Party was an organization advocating violent or

114 Fong Yue Ting v. United States, 149 U.S. 698, 723-24 (1893); Chae Chan Ping v. United States, 130 U.S. 581, 589, 610 (1889) (The Chinese Exclusion Case). 115 E.g., Carpenter v. Pennsylvania, 58 U.S. (17 How.) 456 (1855) ; Calder v. Bull, 3 U.S. (3 Dall.) 386 (1798).

116 E.g., Mahler v. Eby, 264 U.S. 32, 39 (1924) ; Bugajewitz v. Adams, 228 U.S. 585, 591 (1913). Compare Wong Wing v. United States, 163 U.S. 228 (1896).

117 Justices Douglas and Black, 342 U.S. at 598 (dissenting opinion).

$118 I d$. at 595 .

110 Id. at 593. The Court's reference here to 1920 rather than to the year of the original statute (1918) may be to United States ex rel. Abem v. Wallis, 268 Fed. 413 (S.D.N.Y. 1920), the first judicial decision approving an administrative finding that the Communist Party is an organization advocating the violent and forcible overthrow of the Government. Or, the reference may be to the massive "raids" in New England on January 2, 1920, the subject of the litigation in Colyer v. Skeffington, 265 Fed. 17 (D. Mass. 1920). Circuit Judge Anderson's conclusion that the Communist Party was not an organization proscribed in the 1918 act was reversed in Skeffington v. Katzeff, 277 Fed. 129 (1st Cir. 1922).

120342 U.S. at 593.

121 Ibid. See, e.g., note 119 supra; Murdoch v. Clark, 53 F.2d 155 (1st Cir. 1931) ; Antolish v. Paul, 283 Fed. 957 (7th Cir. 1922); United States ex rel. Fortmueller v. Commissioner of Immigration, 14 F. Supp. 484,487 (S.D.N.Y. 1936) ; In re Saderquist, 11 F. Supp. 525 (D. Me. 1935), aff'd sub nom. Sorquist v. Ward, 83 F.2d 890 (1st Cir. 1936). But cf. Ex parte Fierstein, 41 F.2d 53 (9th Cir. 1930), where the court was presented with grossly insufficient evidence, and refused to take judicial notice of the character of the Communist Party. See also United States ex rel. Ohm v. Perkins, 79 F.2d 533 (2d Cir. 1935); Latva v. Nicolls, 106 F. Supp. 658, 661 (D. Mass. 1952) (Wyzanski, J.).

122347 U.S. 522 (1954).

123 Act of Sept. 23, 1950, ch. 1024, \$22(3) (C), 64 Stat. 1006 (now Immigration and Nationality Act of 1952, $\$ 241$, (a) (6) (C), 66 Stat. 204, as amended, 8 U.S.C. $\S 1251$ (a) (6) (C) (1958)). 
forcible overthrow of the Government. Although relying on the decision in Harisiades, ${ }^{124}$ the Court, through Mr. Justice Frankfurter, did not discuss its statement in Harisiades that aliens who joined the party in early years would not be "caught unawares" by a midcentury declaration that their membership had been grounds for deportation since 1920; rather, it seemed to decide only that invalidation of Congress' conclusive classification of the Party and the consequences of membership in it was precluded by the inapplicability of the ex post facto clause to deportation. ${ }^{125}$ However, in disposing of Galvan's argument that he did not know the party was dedicated to violence, the Court relied, as in Harisiades, on the almost plenary power of Congress over the entrance and continued residence of aliens. The Court's failure to discuss the merits of this argument suggests that it concluded, without articulating, that the statutes in the two cases were really identical; that the 1950 act did not establish-or even make more likely to be proved-any ground for deportation which had not existed under the old act. Furthermore, the Court's careful reading of "member" in the new statute to mean more than nominal affiliation ${ }^{126}$ makes it arguable that the Court found no practical retroactivity in the 1950 definition of the Party as a proscribed organization. The construction of "member" at least had the effect of eliminating any retroactive application of new standards of affiliation which would be sufficient for purposes of deportation. While holding petitioner's affiliation to be within the meaning of "member" under prior statutes, the Court-over one majority Justice's dissent ${ }^{127}$ — was at pains to demonstrate that no lesser affiliation constituted membership within the meaning of the new act than under that of 1940 , and even that of $1918 . .^{128}$

124347 U.S. at 530.

125 Id. at 530-31. The Court in Galvan did not discuss this alteration as the element which, in a criminal case, would have brought the act within the ex post facto clause, for although Party members had been consistently deported under the 1918 statute, it appears that the new ease with which this could be done under the 1950 act would fulfill Mr. Justice Chase's fourth definition of an ex post facto law in Calder v. Bull, 3 U.S. ( 3 Dall.) 386, 390 (1789): "Every law that alters the legal rules of evidence, and receives less, or different, testimony, than the law required at the time of the commission of the offence, in order to convict the offender." (Emphasis added.) However, although dispensing with the proof requirement lightened the Government's work load in deportation cases, it is unlikely that the actual burden of proving the case was substantially lessened. The Court left the burden of establishing membership the same, and there had been little trouble under the old act in establishing that the Party was one of the proscribed organizations.

126 See notes 131-35 infra and accompanying text.

${ }_{127} \mathrm{Mr}$. Justice Reed concurred in the judgment and in the opinion as written except as to the deductions from legislative history about the outer limits of membership. 347 U.S. at 532 .

$128 \mathrm{Id}$. at 526-28. The Court found nonexclusive the language of a clarifying amendment to the act in 1951, Act of March 28, 1951, ch. 23, 65 Stat. 28, which explicitly provided for cases of affiliation so nominal as not to be deemed membership: aliens who joined (1) when under sixteen, (2) by operation of law, or (3) to obtain the necessities of life. Significantly, reliance was placed on language from Colyer v. Skeffington, 265 Fed. 17 (D. Mass. 1920), rej'd on other grounds sub nom. Skeffington v. Katzeff, 277 Fed. 129 (1st Cir. 1922), quoted in note 132 infra, which had been inserted in the record by Senator McCarran, the amendment's sponsor, 97 CoNG. REC. 2373 (1951). 
If a desire to avoid or mitigate the rigors of retroactivity moved the Court to this unnecessary demarcation of the outer limits of membership, its summary dismissal of the implication of retroactivity raised by Congress' renunciation of the requirement that the Party's purposes be proved in each case could indicate that whatever retroactivity existed was considered by the Court to be merely formal. It can readily be appreciated that if the standards of what constituted membership had changed, the new law would indeed have imposed a disability for past associations which were previously unproscribed. On the other hand, it was not difficult to conclude that making membership in the Communist Party a specific ground for deportation left the law as developed basically unchanged, the Party having consistently been found to be within the disfavored class under prior statutes. ${ }^{129}$ The least that can be said is that the result, if not the purpose, of the Court's decisions in both Harisiades and Galvan was to construe the 1940 and 1950 acts as having no practical retroactive effect. The dictum in Harisiades that the nature of the Communist Party had long been judicially recognized set the stage for upholding a redefinition of the Party in Galvan; and Galvan, also in dictum, added a gloss to the meaning of "member" which tied the acts of both 1940 and 1950 to the standards of the 1918 act. 130

Like Harisiades, Galvan's broad decision had its progeny, important to the establishment of a complete pattern of nonretroactivity in deportation cases dealing with conduct on the periphery of first amendment liberties. Although Galvan had held that membership within the meaning of the statute did not require that the alien be fully cognizant of the Party's advocacy of violence, it went on to say that nominal affiliation, established unconsciously or by accident, would not suffice to deport.131 This standard, established under the 1918 act ${ }^{132}$ and elaborated by Galvan, was stretched considerably in order to reverse a deportation order in Rowoldt $v$. Perfetto, ${ }^{133}$ which held "meaningful association" ${ }^{134}$ to be necessary-a

120 See note 119 supra; cases cited in note 121 supra.

130 There was, of course, no suggestion in Harisiades that the 1940 act had changed the standard of what constituted membership, inasmuch as the act merely applied to former members of the Party the same sanction that had applied to present members under the 1918 act. See Harisiades v. Shaughnessy, 342 U.S. 580, 588 n.15 (1952). Moreover, Galvan's invocation of Colyer v. Skeffington, 265 Fed. 17 (D. Mass. 1920), rev'd on other grounds sub nom. Skeffington v. Katzeff, 277 Fed. 129 (1st $\mathrm{Cir}$. 1922), emphasizes the fundamental continuity in the legislation. Galvan v. Press, 347 U.' S. 522, 526-28 (1954).

131347 U.S. at $527-28$.

132 "Congress could not have intended to authorize the wholesale deportation of aliens who, accidentally, artificially, or unconsciously, in appearance only, are found to be members of or affiliated with an organization of whose platform and purposes they have no real knowledge." Colyer v. Skeffington, 265 Fed. 17, 72 (D. Mass. 1920), rev'd on other grounds sub nom. Skeffington v. Katzeff, 277 Fed. 129 (1st Cir. 1922). After the Supreme Court's use of Colyer in Galvan, see note 128 supra, the case was followed in this particular in Bovinas v. Savoretti, 146 F. Supp. 274 (S.D. Fla. 1956).

133355 U.S. 115 (1957).

134 Id. at 120. Compare United States v. Killian, 82 Sup. Ct. 302,311 n.5, 312 (1961), where the Court approved a charge in a perjury prosecution under the 
criterion of apparently greater stringency than that laid down in Galvan. Over a vehement dissent by four of his brethren, Mr. Justice Frankfurter, the author of Galvan, aided by this strained statutory construction, summarily dispatched the case by finding the facts, indulgently viewed, too different from those in Galvan to require detailed comparison of the two cases. ${ }^{135}$ In the next case, however, Niukkanen $v$. McAlexander, ${ }^{130}$ the Court sustained a deportation order-Mr. Justice Frankfurter joining the dissenters in Rowoldt to constitute the majority ${ }^{137}$ - by a per curiam opinion which indicated that the Court was unwilling to be the tribunal for further developing the jurisprudence of "meaningful" membership. ${ }^{138}$

It may well be that Rowoldt was but a brief excursion to a position where the elements of deportable membership are viewed more narrowly than they were in the "saving" dictum in Galvan, a journey unnecessary to prolong, but serving to underline a basic continuity of standards between the old and new statutes. Whether or not Rowoldt attempted to set a new standard, it demonstrated vividly that not every former association with the Communist Party is a ground for deportation, and served to imbed the dictum of Galvan into the law surrounding the 1950 statute. This having been achieved, the per curiam disposition of Niukkanen left the finer lines to be drawn-as they were under the older acts-by the lower federal courts. ${ }^{139}$

It may be that to suggest a conscious attempt by the Court to avoid retroactive repression of previously unproscribed association is to glean too

affidavit provision of the Labor Management Relations Act, see note 164 infra, that "membership ... connotes a status of mutuality between the individual and the organization . . [ , a] desire on the part of the individual to belong to the Communist Party and a recognition by that Party that it considers him as its member." The Court sanctioned refusal of an instruction that the acts offered to show membership must indicate agreement with "the illegal purposes or objectives of the communist party as distinguished from mere cooperation with it in lawful activities." Id. at 319 (Douglas, J., dissenting).

135355 U.S. at 121. Mr. Justice Harlan, dissenting, persuasively argued that setting aside the deportation order here could not be reconciled with the Court's holding in Galvan. Id. at 122. But even he did not contend that the 1950 act demanded different standards than its predecessors. Indeed, he claimed that the standards were the same under both acts, and that Galvan had maintained those standards. Id. at 123 n.4. See also Latva v. Nicolls, 106 F. Supp. 658 (D. Mass. 1952) (Wyzanski, J.).

136362 U.S. 390 (1960) (per curiam).

137 Mr. Justice Frankfurter's dictum in Galvan concerning the outer limits of membership had already been used by one district court before he had elaborated upon it in Rowoldt. Bovinas v. Savoretti, 146 F. Supp. 274 (S.D. Fla. 1956).

138 Although the majority predicated their position on the special competence of the trial judge to evaluate the credibility of the testimony concerning the defendant's affiliation with the Party, four Justices from the Rorvoldt majority dissented, finding the facts indistinguishable from those in Rowoldt. 362 U.S. at 394 (dissenting opinion). The difficulty which most of the Justices have in distinguishing Galvan, Rozvoldt, and Niukkanen may explain why the Court, after what appears to have been an inadvertent demarcation of the issue's poles, has abandoned the task of resolution to the lower courts.

139 Compare Bovinas v. Savoretti, 146 F. Supp. 274 (S.D. Fla. 1956), with Grubisich v. Esperdy, 175 F. Supp. 445 (S.D.N.Y. 1959). 
much from the cases. Nevertheless, it can scarcely be denied that practical retroactivity-if it ever existed-has been read out of the statutes. That there is no retroactivity in fact can be stated; that it has been intentionally avoided is arguable. Inasmuch as it is well established that Congress may rely on past activities to effect the deportation of aliens, ${ }^{140}$ hesitancy to permit retroactivity in these cases may be based on an unarticulated belief that there was more at stake than mere unfairness in unexpected deportation. ${ }^{141}$

\section{Public Employment}

Disqualification from gaining or continuing public employment has not enjoyed-or suffered-the long history of litigation as to constitutionality that has surrounded deportation. Perhaps as a consequence, despite Mr. Justice Holmes' unfortunate aphorism about the policeman, ${ }^{142}$ the area has not become enmeshed in formalisms that disqualification can never be punishment ${ }^{143}$ or that because an employee has no vested right in his job he has no rights at all. ${ }^{144}$ Disqualification from public employment differs from deportation in that the demanded qualifications may be examined for a reasonable relationship to the interest which the Government seeks to promote. ${ }^{145}$ But a reasonable relation is easy to find, ${ }^{146}$ and seldom are legislatures so unsophisticated as to make patent the punitive design of a statute depriving persons of employment. ${ }^{147}$ The present relevance of past conduct cannot be dismissed lightly; assuming the pertinence of the associations and activities about which inquiry may be made, those of the past can often provide a proper base from which a full assessment of an employee's or applicant's fitness may be launched. In addition, while few, if any, of the Justices would consider public employment to be

140 See Marcello v. Bonds, 349 U.S. 302 (1955) ; Mahler v. Eby, 264 U.S. 32 (1924); Chae Chan Ping v. United States, 130 U.S. 581 (1889) (The Chinese Exclusion Case).

141 Compare Galvan v. Press, 347 U.S. 522, 532 (Black, J., dissenting); $i d$. at 533 (Douglas, J., dissenting); Harisiades v. Shaughnessy, 342 U.S. 580, 601 (Douglas, J., dissenting).

142 See note 60 supra.

143 Compare United States v. Lovett, 328 U.S. 303 (1946), with Garner v. Board of Pub. Works, 341 U.S. 716, 721-23 (1951). Compare United States v. Lovett, stipra, and Garner v. Board of Pub. Works, sipra, with Marcello v. Bonds, 349 U.S. 302 (1955).

144 Compare United Pub. Workers v. Mitchell, 330 U.S. 75 (1947), with Wieman v. Updegraff, 344 U.S. 183, 192 (1952). See also Chae Chan Ping v. United States, 130 U.S. 581, 589, 610 (1889) (The Chinese Exclusion Case).

145 See Harisiades v. Shaughnessy, 342 U.S. 580, 601 (1952) (dissenting opinion). Compare Shelton v. Tucker, 364 U.S. 479 (1960), zvith Fong Yue Ting v. United States, 149 U.S. 698 (1893).

146 See the discussion of Flemming v. Nestor, 363 U.S. 603 (1960), in note 66 supra; Lerner v. Casey, 357 U.S. 468 (1958). Compare Borrow v. FCC, 285 F.2d 666 (D.C. Cir.), cert. denied, 364 U.S. 892 (1960).

147 See Comment, 63 Y YLE L.J. 844, 845-46 (1954). Compare Garner v. Board of Pub. Works, 341 U.S. 716, 731 (1951) (dissenting opinion). 
a mere "privilege" which legislatures may treat as they will,148 it is clear that constitutional limitations on the state and federal governments in this area do not assume that any person has a "vested right" to a public job. ${ }^{\mathbf{1 4 9}}$

Public service, like deportation, falls in a category generally not reached by the specific constitutional prohibitions of retroactive legislation. The limitations which do apply have been articulated in terms of due process restraints on arbitrary governmental action, ${ }^{150}$ but the Court has displayed a marked deftness-more noticeable than in deportation-at avoiding retroactivity in the statutes and oaths which it has been willing to uphold. Conversely, there has been obvious retroactivity in those statutes, oaths, and inferences which the Court has refused to permit. ${ }^{151}$ Garner $v$. Board of $P u b$. Works ${ }^{152}$ sets the tone for the statutes and oaths affecting association and speech which the Court has sustained. In that case, although Mr. Justice Burton dissented specifically on unconstitutional retroactivity, ${ }^{153}$ the Court held valid a requirement that present and prospective city employees swear that they were not, and had not been, within five years preceding the establishment of the oath, members of any organization advocating the violent or forcible overthrow of the Government. ${ }^{154}$ Finding a reasonable relationship between the city's regulatory interest and the oath imposed, the Court, through Mr. Justice Clark, took great care to show that the test oath requirement only changed the form of an existing legislative stricture: seven years before the test oath requirement was imposed, the city's charter had been amended to prohibit the continued or future employment of anyone belonging to an organization advocating violent or forcible overthrow of the Government. ${ }^{155}$ Challenged on ex post facto grounds, the validity of the oath was placed squarely on the prior charter amendment and the relation of the oath to that amendment.156 Both were found to proscribe the same conduct during the same period of

148 While the term was invoked in Garner v. Board of Pub. Works, supra note 147 , at 722 (criticised in a concurring opinion, id. at 725), and in Adler v. Board of Educ., 342 U.S. 485,492 (1952), it is clear that the state's power to grant and withhold employment is not absolutely unqualified. See Wieman v. Updegraff, 344 U.S. 183 (1952). Compare Speiser v. Randall, 357 U.S. 513 (1958).

149 See Cafeteria Workers v. McElroy, 367 U.S. 886, 894-99 (1961) ; United Pub. Workers v. Mitchell, 330 U.S. 75 (1947); Bailey v. Richardson, 182 F.2d 46 (D.C. Cir. 1950), aff'd by an equally divided Contr, 341 U.S. 918 (1951). See also Garner v. Board of Pub. Works, 341 U.S. 716, 724-25 (1951) (concurring opinion). While there is no "vested right" to a particular job, significantly greater concern is evident when the governmental action threatens continued practice of a chosen trade or profession. See Greene v. McElroy, 360 U.S. 474 (1959) ; Homer v. Richmond, 292 F.2d 719 (D.C. Cir. 1961).

150 Shelton v. Tucker, 364 U.S. 479 (1960) ; Schware v. Board of Bar Examiners,

353 U.S. 232 (1957); Wieman v. Updegraff, 344 U.S. 183 (1952).

151 See cases cited note 150 supra.

152341 U.S. 716 (1951).

153 Id. at 729.

154 Los Angeles, Cal., Ordinance 94004, § 3, Oct. 21, 1948.

155 Cal. Stat. 1941, ch. 67, at 3409 (Charter of Los Angeles, § 432).

156341 U.S. at 720. 
time ${ }^{157}$-a relationship not unlike that found in Harisiades between the Immigration Act of 1940 and its predecessor. ${ }^{158}$

The emphasis in Garner on nonretroactivity has been a recurrent feature in the opinions of the Court which have sustained oaths, ${ }^{159}$ presumptions, ${ }^{160}$ and inquiries ${ }^{161}$ about associational activity. Although the Court has occasionally said that past memberships are relevant to present qualifications, ${ }^{162}$ this kind of language has appeared only in opinions dealing with proscriptions of present associations, and no case has held that employment may be denied because of past activities which were permissible when engaged in.

The statute upheld in American Communications Ass'n v. Douds, ${ }^{163}$ refusing access to the NLRB to unions whose officers had not taken expurgatory oaths regarding affiliations with subversive groups, dealt with disavowal of present associations, ${ }^{164}$ as did the Maryland oath for candidates for public office ${ }^{165}$ in Gerende v. Board of Supervisors. ${ }^{166}$ Similarly,

157 The charter amendment became effective on April 28, 1941, and provided that no person should be retained or be eligible for public office or employment in the City of Los Angeles who, after the effective date of the enactment, became a member of an organization advocating the overthrow by force or violence of the government of the United States or that of California. Cal. Stat. 1941, ch. 67, at 3409 (Charter of Los Angeles, \$432). The subsequent Los Angeles city ordinance required all office holders and employees to take an oath before January 6,1949 , that they had not been members of such an organization within five years prior to the 1948 ordinance. Los Angeles, Cal., Ordinance 94004, $\$ 1$, Oct. 21, 1948. The original charter amendment itself had a five-year retrospective provision, but this was not before the Court. 341 U.S. at 720.

158 See notes 111-21 supra and accompanying text.

159 Gerende v. Board of Supervisors, 341 U.S. 56 (1951) ; American Communications Ass'n v. Douds, 339 U.S. 382 (1950).

180 Adler v. Board of Educ, 342 U.S. 485 (1952).

181 Nelson v. County of Los Angeles, 362 U.S. 1 (1960) ; Lerner v. Casey, 357 U.S. 468 (1958); Beilan v. Board of Pub. Educ., 357 U.S. 399 (1958). But see Konigsberg v. State Bar, 366 U.S. 36 (1961); cf. Barenblatt v. United States, 360 U.S. 109, 126 (1959).

162 See Konigsberg v. State Bar, supra note 161, at 52; Adler v. Board of Educ., 342 U.S. 485, 492-93 (1952); Garner v. Board of Pub. Works, 341 U.S. 716, 720 (1951); cf. Barenblatt v. United States, 360 U.S. 109, 126 (1959).

163339 U.S. 382 (1950).

164 Labor Management Relations Act, ch. 120, $9(\mathrm{~h}), 61$ Stat. 146 (1947). The act prohibited the Board from entertaining the petitions of any union whose every officer had not, within the previous twelve months, executed an affidavit that "he is not a member of the Communist Party or affiliated with such party, and that he does not believe in, and is not a member of or supports any organization that believes in or teaches, the overthrow of the United States Government by force or by any illegal or unconstitutional methods." (Emphasis added.) See Killian v. United States, 82 Sup. Ct. 302, 304-05 (1961). The section was repealed by the Labor Management Reporting and Disclosure Act of 1959, §201(d), 73 Stat. 525. See also \$ 504(a) of the latter act, 73 Stat. 536 (1959), 29 U.S.C. § 504(a) (Supp. II, 1961), which provides, inter alia, for disqualification from holding union office or a labor relations consultant position while a member of the Party or for five years thereafter. This disqualifying provision of the 1959 act has not yet been tested.

165 Md. Ans. Cope art. 85A, §15 (1957), Shub v. Simpson, 196 Md. 177, 76 A.2d 332, appeal dismissed as moot, 340 U.S. 881 (1950).

166341 U.S. 56 (1951). 
New York's Feinberg Law, ${ }^{167}$ which applied to public school teachers, on its surface dealt only with present activities; the act was upheld in Adler v. Board of Education, ${ }^{168}$ with Mr. Justice Burton, who had dissented from what he considered to be Garner's retroactivity, ${ }^{109}$ among the majority. Mr. Justice Frankfurter's dissent in Adler (on the ground that the case and statute were not ripe for review) was based in part on what he felt to be an inability to determine whether the proscriptions of the act applied to past or present associations-an uncertainty as to whether in operation the statute's application would be limited to present associations. ${ }^{170}$

In Lerner v. Casey, $171 \mathrm{Mr}$. Justice Harlan, for the Court, emphasized that the inquiries which the New York subway conductor had refused to answer concerned whether he was "then" a member of the Communist Party; ${ }^{172}$ Lerner's discharge as a security risk was sustained. Retroactivity was likewise absent in Nelson $v$. Los Angeles County, ${ }^{173}$ where petitioners' dismissal from public employment was justified by their "insubordination" in refusing to answer questions put by a congressional committee after they had been ordered to cooperate with the committee both by their superiors and by statute; not only had the inquiry been limited to present associations, but the state statute under which they were dismissed ${ }^{174}$ defined "insubordination" so as to include only refusals to answer questions regarding past activities within a period of time when such activities were, by a separate statute, ${ }^{175}$ grounds for dismissal. ${ }^{176}$

Beilan v. Board of Pub. Educ., ${ }^{177}$ whose acceptance of "incompetency" as cause for dismissal sired Nelson's "insubordination" holding,, ${ }^{178}$ did turn

167 N.Y. Educ. LAws $\$ 3022$.

168342 U.S. 485 (1952).

169 Garner v. Board of Pub. Works, 341 U.S. 716, 729 (1951).

170342 U.S. at 507: "Again, the Rules seem to indicate that past activities of the proscribed organizations or past membership in listed organizations may be enough to bar new applicants for employment. But we do not know, nor can we determine it. This, too, may make a difference," citing Garner v. Board of Pub. Works, 341 U.S. 716, 729 (1951) (Burton, J., dissenting in part).

171357 U.S. 468 (1958).

$172 I d$. at 471 . See also $i d$. at 474.

173362 U.S. 1 (1960).

174 CAL. Gov't CODE $\$ 1028.1$.

175 Cal. Gov't CoDE $\$ 1028$.

176 The oath in force at the time of the facts which gave rise to Nelson, CAL. Gov'T CODE $\$ 1028.1$, provided for discharge for any failure to answer questions about past knowing membership "at any time since September 10, 1948," presumably to confine the time period within the scope of $\S 1028$, which was added by Cal. Stat. 1947 , ch. 1418, $\$ 1$, at 2976 . Subsequently, the oath was amended to extend the time period back to October 3, 1945. Cal. Stat. 1957, ch. 2106, \&1, at 3731. This amendment confines the oath carryback to a period covered by yet another statute, CaL. Gov'T CoDe $\$ 18200$, passed in 1945.

177357 U.S. 399 (1958).

178362 U.S. at 7. Lerner v. Casey, 357 U.S. 468 (1958), was also cited as controlling Nelson, another factor indicating that the Court in Nelson did not think itself faced with a question of retroactivity or remoteness. See note 172 supra and accompanying text. 
on a chain of events begun by a question as to specific past Communist activity. In this respect the case is not immediately reconcilable with the cases before and after it which upheld tests of only present subversive association. The question which Beilan's superintendent asked him had related to supposed Communist affiliation and activities in 1944, before any Pennsylvania law made such association a disqualification from employment. ${ }^{179}$ But in upholding Beilan's discharge, the Court made clear that it did not consider the question as having any independent significance, since, by his refusal, Beilan indicated that he would not answer any similar question relating to his associations-past or present. ${ }^{180}$ Moreover, the Court (speaking through Mr. Justice Burton, who, it will be recalled, had dissented in Garner from what he believed to be a sanctioning of retroactivity ${ }^{181}$ ) pointedly said that Beilan had not even challenged the questions put to him on grounds of remoteness. ${ }^{182}$

In Konigsberg $v$. State $B a r,{ }^{183}$ a five-Justice majority, categorically asserting that there are no "absolutes" in the first amendment, ${ }^{184}$ gave the appearance of having abandoned the concern for avoiding retroactivity which was so evident in Garner and Beilan. Broadly citing those cases as holding that "the State's interest in ascertaining the fitness of the employee for the post he holds" outweighs "the interest in not subjecting speech and association to the deterrence of subsequent disclosure," 185 the Court seemed to suggest that any past speech and association may be a valid ground for repressive sanctions if an adequate "interest" can be found. Under the presumption of constitutionality which a majority of the Court now entertains, ${ }^{186}$ it would seem that an adequate interest must be found unless there is something in the statute in question specifically to

179 Pennsylvania's first provision for the discharge of teachers in the "security area" was passed in 1949, and was at that time part of the law under which Beilan was discharged for "incompetency." PA. STAT. ANN. tit. 24, \$11-1122 (1950). The clause "advocation of or participating in un-American or subversive doctrines" was deleted from this act, as of March 1, 1952, by Pennsylvania Loyalty Act $\$ 16, \mathrm{~Pa}$ Laws 1951, act 463. The Loyalty Act provides its own sanctions-and an oath requirement. PA. Stat. ANN. tit. 65, \$\$ 211-25 (1959).

180 When Beilan refused to answer the specific question posed, he also announced he would "decline to answer any other 'questions similar to it,' 'questions of this type,' or 'questions about political and religious beliefs . . . '" 357 U.S. at 401.

181 Garner v. Board of Pub. Works, 341 U.S. 716, 729 (1951).

182357 U.S. at 405 : "Petitioner is not in a position to challenge his dismissal merely because of the remoteness in time of the 1944 activities. It was apparent from the circumstances of the two interviews that the Superintendent had other questions to ask. Petitioner's refusal to answer was not based on the remoteness of his 1944 activities. He made it clear that he would not answer any questions of the same type as the one asked. Petitioner blocked from the beginning any inquiry into his Communist activities, however relevant to his present loyalty." Cf. Barenblatt v. United States, 360 U.S. 109, 114 (1959). Compare Lerner v. Casey, 357 U.S. 468, 471 (1958).

183366 U.S. 36 (1961).

184 Id. at 49.

185 Id. at 52 .

186 See note 84 sipra. 
rebut it. ${ }^{187}$ But Konigsberg's unrestrained language need not determine the issue of retroactivity; the case was squarely placed on Beilan, ${ }^{188}$ and this may well be sufficient for present purposes, since Konigsberg's refusal to answer the bar examiners' questions, like Beilan's, was premised on what he believed to be the constitutional impermissibility of any such questions, rather than on the remoteness of some of them. ${ }^{189}$ To make Beilan controlling in Konigsberg, as the Court did, does not require reading the earlier case broadly; as far as retroactive condemnation of a past exercise of freedom of association is concerned, the facts of Konigsberg do not remove that case from the scope of a narrowly read Beilan-a Beilan consonant with the meticulous avoidance of retroactivity in Garner. Care must be taken, however, that no subtle accumulation of a body of dicta condoning unqualified inquiry into past uninhibited associations obscures what the Court has actually decided to date. Unfortunately, Konigsberg manifests a blurring of the issue when decision on inquiries into the past is unnecessary and consequently unconsidered. ${ }^{190}$

The only federal case to come near presenting the Court with the issue posed by the state cases is Bailey $v$. Richardson, ${ }^{191}$ where discharge of a federal employee for security reasons ${ }^{192}$ was grounded on certain unrevealed information obtained through investigations of the employee's associations. Without referring to whether the evidence which was adduced before the federal agencies related to past or present activities, the Court of Appeals for the District of Columbia sustained the discharge over an impassioned dissent by Judge Edgerton. ${ }^{193}$ The Supreme Court, equally divided, affirmed. ${ }^{194}$ Since no explanation was given as to the temporal relevance of the evidence which allegedly gave reason to question Miss Bailey's loyalty, and since the major issue before the court of appeals

187 Compare Flemming v. Nestor, 363 U.S. 603 (1960), discussed in note 66 supra. 188 Konigsberg v. State Bar, 366 U.S. 36, 53-56 (1961). There was also an additional problem with the burden of proof-whether the petitioner or the bar examiners should bear it. Speiser v. Randall, 357 U.S. 513 (1958), was distinguished. 366 U.S. at $53-56$.

188366 U.S. at 38 n.1. See also Konigsberg v. State Bar, 353 U.S. 252, 306 (1957) (dissenting opinion).

$190 \mathrm{Cf}$. Barenblatt v. United States, 360 U.S. 109, 126 (1959). See also Adler v. Board of Educ., 342 U.S. 485, 493 (1952).

191182 F.2d 46 (D.C. Cir. 1950), aff'd by an equally divided Court, 341 U.S. 918 (1951).

192 Under Exec Order No. 9835, 12 Fed. Reg. 1935 (1947).

193182 F.2d at 66. The majority's conclusion-"that the President, absent congressional restriction, may remove from Government service any person of whose loyalty he is not completely convinced . . . without assigning any reason and without giving the employee any explanatory notice," $i d$. at 65 -was recently echoed in Cafeteria Workers v. McElroy, 367 U.S. 886, 894, 898 (1961), although the Court there made clear that a "patently arbitrary or discriminatory" reason would be unacceptable, as might be one which stigmatized the employee as disloyal. Id. at 898 . "That is, unless the government official is foolish enough to admit what he is doing -and few will be so foolish after ... [this] decision-he may employ 'security requirements' as a blind behind which to dismiss at will for the most discriminatory of causes." Id. at 900 (Brennan, J., dissenting).

194341 U.S. 918 (1951). 
was lack of confrontation, ${ }^{195}$ it cannot be said that the case detracts from the general conclusions that can be drawn about the Supreme Court's avoidance of the retroactive proscription of organizational ties. ${ }^{186}$ Clearly, the possibility that the court of appeals may have known of underlying inquiries into past associations ${ }^{197}$ cannot make Bailey-concerned as it is with confrontation-precedent for unqualifiedly permitting dismissal to be predicated upon investigation into prior lawful associations. Furthermore, it must be noted that the investigations in Bailey may have had sufficient relevance to the standards of the Hatch Act of 1939198 to avoid the vice of retroactivity, since that act prohibited federal employment of members of any political party or organization advocating the overthrow of the Government. ${ }^{199}$ Perhaps the most notable feature of Bailey is that it demonstrates that the import of retroactivity as a distinct kind of infringement of first amendment liberties has not received full articulation by either courts or counsel.

The public employment cases, while primarily focused on the reasonableness of the specific legislation in each case as a means of achieving a legitimate governmental goal, have not shown the Court to be unaware of the dangers inherent in the retroactive prescription of disabilities for activities in the past. The care taken in Garner to avoid retroactivity is in itself significant; subsequent emphasis on the fact that those inquiries which have been sustained were addressed to present conduct heightens the significance. Only Konigsberg failed to differentiate specifically between past and present associations, and it is clear that no member of the Court in that case thought past activities to be the issue. ${ }^{200}$

195 See 182 F.2d at 65. Miss Bailey had also been barred from government service for three years. This part of the discharge proceedings was held invalid as a bill of attainder, 182 F.2d at 55, citing United States v. Lovett, 328 U.S. 303 (1946).

196 However, support for a theory that retroactivity has been avoided is hard to glean from those cases in which federal discharges have been invalidated through construction of the statute involved or on procedural grounds. E.g., Vitarelli v. Seaton, 359 U.S. 535 (1959) ; Service v. Dulles, 354 U.S. 363 (1957) ; Cole v. Young, 351 U.S. 536 (1956) ; Peters v. Hobby, 349 U.S. 331 (1955) ; cf. Greene v. McElroy, 360 U.S. 474 (1959).

197 The evidence before the two loyalty review boards indicated that Miss Bailey had been an active and leading member of the Communist Party in the District of Columbia from about 1935 to 1943. Gardner, Bailey v. Richardson and the Con stitution of the United States, 33 B.U.L. REv. 176, 177 (1953).

108 Act of Aug. 2, 1939, ch. 410, $\$ 9 A, 53$ Stat. 1148 (repealed by the Act of Aug. 9, 1955, ch. $690, \S 4,69$ Stat. 625$)$.

199 The executive order authorizing the regulations which led to Miss Bailey's dismissal, 5 C.F.R. $\$ 2.104$ (1949), also provided for the Attorney General's listing of subversive organizations to aid in policing the Government's loyalty program. Exec. Order No. 9835, 12 Fed. Reg. 1935 (1947). Organizations, including the Communist Party, to which Miss Bailey allegedly belonged or had belonged, were listed pursuant to the order. 182 F.2d at 49-50. Compare the discussion at notes 121-29 supra of the legislative determination for purposes of deportation that the Communist Party is an organization advocating the violent or forcible overthrow of the government.

200 While four members of the Court vigorously dissented, they did not address themselves to any retroactive or remote aspects of the questions asked. Konigsberg v. State Bar, 366 U.S. 36, 56, 80 (1961). These Justices, however, have not been insensitive to remoteness in other instances. See Watkins v. United States, 354 U.S. 178, 197 (1957); Schware v. Board of Bar Examiners, 353 U.S. 232, 24446 (1957); Wieman v. Úpdegraff, 344 U.S. 183, 193 (1952) (Black, J., concurring). 
There may be granted, as has been done with regard to deportation, a largely uninhibited power within legislatures, both state and federal, to control their own housekeeping. Although the protections of the fifth and fourteenth amendments may be more generously applied to mollify the impact of the sovereign on citizen-employees than in the case of aliens, one may accept the idea-assuming no patently discriminatory classifications are employed-that in general governments need not justify their firing practices in each individual instance. But the exercise of this power may not be predicated on grounds which, through retrospective imposition of disabilities and hardships for past conduct, threaten to constrict the free exercise of first amendment rights in the future.

\section{B. Statutes Which Create Disadvantages Different From Those Existing at the Time of Action}

Deportation, as the archetype of those retrospective impositions which have almost formalistically been held to fall outside the strictures of the ex post facto clause, demonstrates the license with which harsh and retroactive legislation may operate when there is no threat to the continued exercise of fundamental freedoms. Marcello v. Bonds ${ }^{201}$ is a recent and striking example. The petitioner, legally resident in this country since the age of eight months, had been convicted of a single violation of the Marihuana Tax Act ${ }^{202}$ in 1938, when one offense was not grounds for deportation. The Immigration and Nationality Act of 1952, however, not only made one such conviction sufficient cause for deportation, ${ }^{203}$ but authorized deportation on the basis of a conviction obtained before its enactment. ${ }^{204}$ With only one of the three dissenting Justices attacking the ex post facto effect of the act, ${ }^{205}$ the Court sustained Marcello's deportation under the 1952 law. This statute, as applied to Marcello, is a marked example of a new and substantial disadvantage imposed for past conduct; but, as usual, the majority dispatched the ex post facto challenge on the ground that deportation is not punishment. ${ }^{208}$ Otherwise, the clause would have been clearly applicable. ${ }^{207}$

The new imposition in Marcello was so substantial that, if it could have been anticipated, it might have changed the offender's course of conduct. While a law's effect on voluntary action does not determine the

201349 U.S. 302 (1955).

202 Ch. 553, § 6, 50 Stat. 553 (1937) (now INT. Rev. Code of 1954, § 2591).

20366 Stat. 204, 8 U.S.C. $\$ 1251$ (a) (11) (1958).

20466 Stat. 208, 8 U.S.C. $\$ 1251$ (d) (1958).

205349 U.S. at 319 (Mr. Justice Douglas).

206 Id. at 314, citing Galvan v. Press, 347 U.S. 522 (1954), and Harisiades v. Shaughnessy, 342 U.S. 580 (1952).

207 In a criminal context, even reducing the jury from twelve to eight has been held ex post facto as applied to one whose crime had been committed in the time of the twelve-man jury. Thompson v. Utah, 170 U.S. 343 (1898). See also Duncan v. Missouri, 152 U.S. 377 (1894); Hopt v. Utah, 110 U.S. 574 (1884) (dictum). 
applicability of the ex post facto clauses, ${ }^{208}$ a different view may be taken of retroactivity when there is added to the inequitable treatment of an individual a threat to the continued exercise of first amendment liberties. ${ }^{209}$ Had, for example, Marcello's early offense been picketing to secure union recognition ${ }^{210}$ or the abolition of the draft, ${ }^{211}$ subsequent classification of his conduct as a ground for deportation would be such an alteration of the disabilities which may possibly be attached to conduct on the periphery of the first amendment that future similar activities would be appreciably curtailed. Conduct willingly undertaken at the risk of incurring present disabilities might be overwhelmingly deterred by the prospect of unforeseeable consequences. Assuming that aliens may be prospectively forbidden to engage in certain activities on the border of the first amendment, the retroactive establishment of significant disadvantages for having engaged in the same activities would remain unacceptable because of the virtually unlimited effect of the possibility of similar impositions in the future upon the continued exercise of free speech and association.

On the other hand, new regulations which may come close to trespassing on freedom of speech and association may be so insubstantial by comparison to those in force at the time of action that no course of conduct would have been altered by the prospect of them; likewise, the threat of similar retroactive regulations in the future which apply to currently proscribed activity should not generate any anxiety not already produced by the existing sanctions. Flemming $v$. Nestor ${ }^{212}$ is a case in point. A 1954 amendment to the Social Security Act ${ }^{213}$ provided for the termination of old-age benefits payable to aliens deported after its enactment for certain causes under the Immigration and Nationality Act of 1952.214 Nestor, who began receiving benefits in 1955, was deported after the amendment, but his deportation was based on his having been a member of the Communist Party from 1933 to 1939 . Deportation on this ground was one of the causes for which benefits could be cut off. ${ }^{215}$ Over the dissent of four

208 Such an effect is not a prerequisite to invoking the ex post facto clause, see note 207 supra, nor, on the other hand, is it necessarily sufficient, see Galvan v. Press, 347 U.S. 522 (1954); Harisiades v. Shaughnessy, 342 U.S. 580 (1952) ; Mahler v. Eby, 264 U.S. 32 (1924); cf. Chae Chan Ping v. United States, 130 U.S. 581 (1889) (The Chinese Exclusion Case) (alien left country with certificate to readmit him; all certificates cancelled in his absence).

209 Compare Galvan v. Press, 347 U.S. 522, 532 (1954) (Black, J., dissenting) ; id. at 533 (Douglas, J., dissenting); Harisiades v. Shaughnessy, 342 U.S. 580, 600 (1952) (Douglas, J., joined by Black, J., dissenting).

210 See the discussion of the arrests during bitter labor disputes at California shipyards in 1934, Schware v. Board of Bar Examiners, 353 U.S. 232, 241-42 (1957). 211 Compare Abrams v. United States, 250 U.S. 616, 629-31 (1919) (Holmes, J., dissenting).

212363 U.S. 603 (1960).

21368 Stat. 1083 (1954), as amended, 42 U.S.C. $\S 402$ (n) (1958).

21466 Stat. 204, 8 U.S.C. $\$ 1251$ (a) (1958).

215 Section 202(n) of the Social Security Act, added by 68 Stat. 1083 (1954), as amended, 42 U.S.C. $\$ 402(\mathrm{n})$ (1958), specifies that benefits shall be terminated for those deported under $\$ 241$ (a) (6) (C) (i) of the Immigration and Nationality Act of 1952, 66 Stat. 205, 8 U.S.C. $\$ 1251$ (a) (6) (C) (i) (1958). 
Justices, the Court upheld the termination of Nestor's payments. Viewing this action as regulation within the Social Security scheme rather than as an adjunct of the deportation laws, ${ }^{216}$ the majority was able to conclude that the statute was not an attempt to punish for past disfavored conduct. ${ }^{217}$ In fact, the Court's opinion, by Mr. Justice Harlan, relegated to footnote Nestor's contention that his first amendment rights were being violated; because they saw the termination of benefits as flowing from deportation rather than from prior Communist affiliation, the majority disposed of the first amendment argument as merely a collateral attack on the original deportation order. ${ }^{218}$

If the majority's conclusion that the withdrawal of Nestor's benefits was a regulation reasonably related to the operation of the Social Security scheme can be accepted, the decision seems constitutionally unimpeachable. If, as the majority also decided, the cutoff did not deprive Nestor of an accrued property right, ${ }^{219}$ and was not punishment which should fall before the ex post facto clause or the requirement of a judicial trial, ${ }^{220}$ its retroactivity could be challenged only from a first amendment perspective. It is in this area that the statute's reasonable relation to other admittedly valid legislation should not have saved it if past associations would thus become the basis for substantial disadvantages which could not have been anticipated. ${ }^{221}$ However, the addition to existing sanctions of the loss of Social Security benefits would hardly seem to be such an increase of the preexisting disadvantage of deportation that, if foreseen, it would have deterred the conduct in question. The added disability in Nestor for previously proscribed association is not incompatible with the generalization that in the area of first amendment liberties-in contrast to those nonfirst amendment situations represented by the facts in Marcello-the Court has not permitted retroactive impositions which would have been likely to have altered the course of action which was in fact taken. ${ }^{222}$

\section{Statutes Which Affect Previously Innocent Conduct}

The element of retroactivity is a significant feature of those cases in which the Court has held inferences drawn from, or inquiries into, past

216363 U.S. at 611-12. See note 66 supra.

217 Id. at 617 . See note 36 supra.

218 Id. at 613 n.7, 619-20.

$219 I d$. at 608-11.

220 See $i d$. at 617 .

221 See text accompanying notes $96-97$ supra. Note that it is irrelevant that the new disability is considered a consequence of the old disability rather than a new sanction against the underlying offense. In the Nestor situation, then, the Court's conclusion that termination of benefits flowed from deportation rather than from Congress' displeasure with the conduct for which deportation was imposed, 363 U.S. at 619 , should not suffice to sustain the statute if it would alter conduct on the first amendment periphery.

222 The comparison must be made to the line of cases following Garner v. Board of Pub. Works, 341 U.S. 716 (1951), see notes 152-57 supra and accompanying text, and that following Wieman v. Updegraff, 344 U.S. 183 (1952), see notes 223-28 infra and accompanying text, inasmuch as only Nestor has presented the issue in the context of a new disability imposed for previously proscribed conduct. 
associations to be arbitrary and unreasonable. Thus Wieman v. Updegraff ${ }^{223}$ invalidated, in the absence of a scienter requirement, an Oklahoma test oath ${ }^{224}$ which required teachers to disavow past membership in certain organizations. In contrast to Garner, there was no prior Oklahoma law dealing with those past activities which the oath was intended to uncover. ${ }^{225}$ Mr. Justice Clark, for a unanimous Court, distinguished Garner, Adler, and Gerende on the ground that in those cases the statutes implicitly made disqualification turn on knowledge of the organizational purposes of the groups in which membership carried the sanction of unemployability. ${ }^{226}$ The opinion clearly manifests a concern with the legislation's inhibiting effect on the future exercise of first amendment freedoms, ${ }^{227}$ and, in fact, Mr. Justice Black's concurring opinion found a bill of attainder in the resurrection of the five years preceding the taking of the oath.228

In Schware v. Board of Bar Examiners, 229 the Court was again confronted with a disqualifying inference drawn from past membership in the Communist Party at a time when membership entailed no similar disadvantage-when in fact the party enjoyed a place on New Mexico's ballot.230 The case differs from Wieman only in that the inference in Wieman was drawn automatically from a refusal or inability to take the exculpatory oath, while in Schware the inference was drawn by a board of examiners from an admission of past membership. The decision in Schware did not turn on scienter alone, as it had in Wieman, but also on the impermissibility of resting a conclusion that the applicant presently lacked good moral character upon Party ties which had been severed fifteen years earlier. ${ }^{231}$ The cases are similar in that the inference in

223344 U.S. 183 (1952).

224 Okla. Sess. Laws 1951, tit. 51, ch. 1, §§ 1-9.

225 See Garner v. Board of Pub. Works, 341 U.S. 716, 720 (1951). Compare Wieman v. Updegraff, 344 U.S. 183, 193 (1952) (concurring opinion). Similarly, the Florida statute which the Court unanimously upset in Cramp v. Board of Pub. Instruction, 82 Sup. Ct. 275 (1961), called for an oath by public employees "that I have not and will not lend my aid, support, advice, counsel or influence to the Communist Party," Fia. Stat. ANN. \$876.05 (Supp. 1960). Although the oath requirement, enacted in 1949, Fla Laws 1949, ch. 25046, $\$ 1$, was preceded by a 1941 law making criminal the advocacy of "doctrines that existing form of constitutional government should be overthrown by force or violence or by any other unlawful means ..." Fla. Stat. ANN. \$ 876.01 (1944), as amended, Fla. Stat. ANN. \$ 876.01 (Supp. 1960), there was no prior law referring to the Communist Party as such, and in any event, as the Court noted, the oath requirement looked back into "the unending past," 82 Sup. Ct. at 280, not just to 1941 . The opinion, however, relied principally on the unconstitutional vagueness of the words "aid, support, advice, counsel or influence": "could anyone honestly subscribe to this oath who had ever supported any cause with contemporaneous knowledge that the Communist Party also supported it?" Ibid. See generally, as to the relationship between the void-for-vagueness doctrine and the first amendment, Note, The Void-for-Vagneness Doctrine in the Silpreme Court, 109 U. PA. L. REV. 67 (1961).

226344 U.S. at 188-91.

227 Id. at $190-91$.

228 Id. at 193.

220353 U.S. 232 (1957).

$230 \mathrm{Id}$. at $244 \mathrm{n.14}$.

231 Id. at $243-46$. 
Schware and the classification in Wieman were both founded on the same unconstitutional assumption, and in both cases the operative conduct had carried no detrimental consequences at the time in question.

Outside the arena of "security" legislation, the Court recently struck down an Arkansas statute requiring all teachers, as a condition of employment, to disclose every organization of which they had been members or to which they had contributed money within the last five years. ${ }^{232}$ Shelton $v$. Tucker, ${ }^{233}$ while acknowledging the right of a state to make some inquiries into a teacher's extracurricular activities, ${ }^{234}$ invalidated the statute because of its "unlimited and indiscriminate sweep." 235 Thus the Court did not reach the question whether, had it not been overbroad, the statute must fall as a retroactive imposition of a disadvantage for past lawful affiliations. However, although the majority was apparently satisfied that even the prospective operation of such a broadly drawn statute would be invalid, it may be argued that the element of retroactivity was itself a constitutional infirmity. ${ }^{238}$ On the other hand, it is at Shelton that one approaches the magic line between formally imposed disabilities and informal consequences collateral to disclosure; there was no valid law in Arkansas prohibiting the employment of teachers whose affiliations evinced an endorsement of racial integration. ${ }^{237}$ Implicit in the position taken by the four dissenters is a distinction between outright prohibition of certain associations-or disqualification for having previously engaged in themand mere compulsory revelation without specific consequences; ${ }^{238}$ the

232 Ark. Acts 2d Extraordinary Sess. 1959, No. 10.

233364 U.S. 479 (1960).

234 Id. at $485,487-88$.

235 Id. at 490 . Accepting, as it did, the possible relevance of such inquiries to legitimate state interests, the Court's invalidation of the statute was rested on the broad constitutional principle expressed in Cantwell v. Connecticut, 310 U.S. 296, 304 (1940): "In every case the power to regulate must be so exercised as not, in attaining a permissible end, unduly to infringe the protected freedom." See text following note 93 supra; cf. Wolfe v. City of Albany, 104 Ga. App. 264, 121 S.E.2d 331 (1961), in which a state court of appeals held unconstitutional a city ordinance requiring, inter alia, an applicant to show that he never belonged to any "Communistic" organization before he may be licensed to solicit members for any dues paying association. The decision, which found the ordinance to be an unreasonable exercise of the police power, was rested on both state and federal free speech provisions.

236 Compare Cramp v. Board of Pub. Instruction, 82 Sup. Ct. 275 (1961), discussed in note 225 supra; Schware v. Board of Bar Examiners, 353 U.S. 232 (1957); Wieman v. Updegraff, 344 U.S. 183 (1952).

237 Ark. Acts 1959, No. 115, passed in the same year as the statute before the Court in Shelton, did make it unlawful for any member of the National Association for the Advancement of Colored People to be employed by the state of Arkansas or any of its subdivisions. The trial court in Shelton held this law invalid under the fourteenth amendment, at the same time that it sustained the disclosure provision which the Supreme Court subsequently overturned. Shelton v. McKinley, 174 F. Supp. 351 (E.D. Ark. 1959), rev'd sub nom. Shelton v. Tucker, 364 U.S. 479 (1960).

238 In an opinion by Mr. Justice Harlan, the four dissenting Justices stated in general terms that "information about a teacher's associations may be useful to school authorities in determining the moral, professional, and social qualifications of the teacher, as well as in determining the type of service for which he will be best suited in the educational system." Shelton v. Tucker, 364 U.S. 479, 498 (1960) (dissenting opinion). In an opinion by Mr. Justice Frankfurter, in which all the dissenting 
case was so explained when these Justices captured a majority in Konigsberg, ${ }^{239}$ where the Court found no specific disadvantage necessarily consequent to disclosure. ${ }^{240}$

This importance to some members of the Court of officially imposed disadvantages flowing from a state or federal inquiry is evident in the cases on legislative investigations, where questions as to past unproscribed associations have been approached differently than in the context of public employment or admission to the bar. ${ }^{241}$

Before these cases are discussed, one premise should be made explicit. There is a significant distinction between the power to legislate per se and the power to investigate in areas of legislative competence: Congress may investigate where it may properly legislate, ${ }^{242}$ but the scope of inquiry -assuming its pertinence to a proper legislative goal-need not be confined to the narrow terms of the statute to which an investigation may give rise. A congressional investigation of previous criminal conduct in order to enact more effective controls upon interstate racketeering is not likely to be considered a serious retrospective hardship on a former offender who is questioned-even though formal punishment of such distant conduct would be clearly unconstitutional. ${ }^{243}$ While the witness may be exposed to public scorn, it may be doubted that the threat of such a disadvantage in the future would deter conduct already proscribed by the

Justices joined, a specific justification was suggested for the Arkansas law: "Presumably, a teacher may have so many divers associations, so many divers commitments, that they consume his time and energy and interest at the expense of his work or even of his professional dedication." Id. at 494. The act's scrutiny of associations of the prior five years weakens the force of the dissenters' assertion of relevance, as do the questions regarding contributions. Insofar as disadvantages may attend revealing certain associations, the statute clearly conflicts with the protections of the first amendment. Here may lie the division in the Court; the majority foresaw disabilities flowing from revelation-explicitly in the possibility of publication, id. at 486, sub silentio in the possibility of discriminatory firing, see $i d$. at 485 n.5. The dissent refused to read this into the statute, preferring to decide that case if and when it should arise. Id. at 499.

239366 U.S. 36, 53 (1961). The Konigsberg majority suggested that in Shelton there was the possibility that the state might be afforded the opportunity for imposing "undetectable arbitrary consequences upon protected association." Ibid.

$240 \mathrm{Ibid}$. Insofar as the inquiries are directed at present activities, these Justices might also conclude that even though "an angry public opinion, and the evils which it may spawn, are relevant considerations in adjudging ... the validity of legislation that, in effecting disclosure, may thereby entail some restraints on speech and association, the existence of an ugly public temper does not, as such and without more, incapacitate government to require publicity demanded by rational interests high in the scale of national concern." Communist Party v. Subversive Activities Control Bd., 367 U.S. 1, 102 (1961). The majority there makes very clear that the only question properly before them concerned the registration provisions of $\$ 7$ of the act, 64 Stat. 993 (1950), as amended, 68 Stat. 586 (1954), 50 U.S.C. \$ 786 (1958). Id. at 70-81. That section is addressed to current activities only. Id. at 86-87.

241 See Barenblatt v. United States, 360 U.S. 109, 128 (1959).

242 Id. at 117-22.

243 Compare Narcotic Control Act of 1956, 18 U.S.C. \$1406 (1958), which requires, under threat of contempt, the testimony of any witness before any grand jury or court of the United States examining possible violation of certain narcotic statutes. The privilege against self-incrimination is replaced by a pledge of immunity from prosecution. 
criminal laws. However, investigations in the area of speech and association have inevitably turned their pressure upon persons whose past conduct is likely to have been within the protection of the first amendment. While the deterrent effect on a given witness, as contrasted with the ex-racketeer, is not unimportant, the effect may reverberate far beyond the witness and constitute a considerable inhibition-though admittedly weaker than that posed by retroactive legislation-to the continued exercise of first amendment rights. ${ }^{244}$

Although the earliest investigation cases in the area of national security were consistent with an avoidance of retroactive condemnation of past speech and association, the cases have failed to develop a pattern which parallels that found in the decisions on job disqualification or deportation. Watkins v. United States ${ }^{245}$ and Sweezy v. New Hampshire, ${ }^{248}$ invalidating contempt convictions on broad first, fifth, and fourteenth amendment grounds, necessarily obviated any objections to the retrospective nature of the questions which had there been asked. ${ }^{247}$ Language in Watkins that legislative investigations impose hardships not unlike those inflicted by legislative disqualifications from employment," 248 and that "this effect is even more harsh when it is past beliefs, expressions or associations that are disclosed and judged . . ..," 249 suggested that the investigation cases might develop consistently with the Court's practice of avoiding retroactivity in the area of speech and association. Three of the four subsequent cases can be so reconciled. ${ }^{250}$ But Barenblatt $v$. United States, ${ }^{251}$ a further refinement of Watkins, seems to permit congressional investigators to reach into the past even where the conduct made subject to inquiry lies

244 But cf. Ullman v. United States, 350 U.S. 422 (1956), holding constitutional the Immunity Act of 1954, 18 U.S.C. $\$ 3486$ (1958). The Court held that, while the immunity conferred upon a witness required to testify before a federal grand jury investigating threats to national security from espionage might not secure him against all disabilities consequent to his testimony, the demands of the fifth amendment were sufficiently met by the promise of immunity from formal prosecution. Id. at 430-31. While the Court did not attempt to delineate the exact scope of the statute's protection, it did note the right of a witness faced with sanctions of any type to claim that they are criminal in nature. $I d$. at 431 . In view of the majority's continued refusal to consider the most likely disabilities-loss of job, passport ineligibility, deportation, public scorn-as punishments, this right would seem illusory. It must be noted, however, that insofar as the demanded testimony goes to prior criminal activity, the decision's implicit condonation of additional sanctions for already proscribed conduct does not vitiate the thesis that the first amendment would bar the assignment of similar disabilities to previously legal activities in the realm of speech and association.

245354 U.S. 178 (1957).

246354 U.S. 234 (1957).

247 Watkins was asked whether several of his past associates had been members of the Communist Party. 354 U.S. at 178, 185. Sweezy was asked about prior contacts with Communists. 354 U.S. at $234,242$.

248354 U.S. at 197-98.

$249 \mathrm{Id}$. at 197.

250 See Wilkinson v. United States, 365 U.S. 399 (1961) ; Uphaus v. Wyman, 360 U.S. 72 (1959). Braden v. United States, 365 U.S. 431 (1961), can be included in this group inasmuch as the unanswered question reviewed by the Court went to membership which appears to have been virtually contemporaneous with the investigation.

251360 U.S. 109 (1959). 
on the periphery of the first amendment and was not proscribed when it was undertaken. 252

With the wisdom born of hindsight, one can view Barenblatt as foreshadowed by the various positions of the Justices in earlier investigation cases. ${ }^{253}$ More clearly, it seems to be the fruition of Mr. Justice Clark's dissents in Sweezy ${ }^{254}$ and Watkins. ${ }^{255}$ In neither case did he find infringement of first amendment rights or problems raised by questions regarding past activities and associations. ${ }^{256}$ Most significantly, he drew a distinction between the informal stigma, scorn, and obloquy that result from exposure in a legislative investigation and the disgrace and hardship that accompany loss of a job as a security risk; ${ }^{257}$ it was clear to him that Watkins and Sweezy did not pose the same problems that faced the Court when he wrote the opinion invalidating Oklahoma's test oath in the Wieman case. 258

That this distinction may be determinative for a majority of the Court was recently implied in Konigsberg, in which Mr. Justice Harlan drew a line between disclosures which themselves result in specific disabilities, and revelations which do not necessarily result in harmful consequences. ${ }^{259}$ This line, while far from convincing as a means of deciding Barenblatt in the first place, ${ }^{260}$ is appealing insofar as it may serve to limit that case to its facts; that is, even if Barenblatt has foreclosed the issue of retroactivity in legislative investigations, to distinguish between officially imposed disabilities and informal disadvantages would preserve the disqualificationdisbarment-deportation area free from similar retroactive impositions with respect to speech and association. Certainly Barenblatt should remain limited to legislative investigations and should not be transplanted into those areas where directly imposed governmental disabilities flow from in-

252 Although Barenblatt refused on first amendment grounds to answer any questions regarding associational activities or political beliefs, $c f$. Beilan v. Board of Pub. Educ., 357 U.S. 399 (1958), the Court made decision on past membership inquiries part of the case by its statement of the issue. 360 U.S. at 126 .

253 Thus, Mr. Justice Frankfurter limited his concurrence in Watkins to the inadequate notice given the petitioner as to the relevance of the questions asked, 354 U.S. at 217; and he and Mr. Justice Harlan confined their concurrence with the result in Sweezy to New Hampshire's inadequate interest in ascertaining the petitioner's relationship to and knowledge about the Progressive Party, which could not be classified along with the Communist Party as a threat to the security of New Hampshire. 354 U.S. at 266 .

254354 U.S. at 217.

255354 U.S. at 267.

$256 I d$. at $268 ; 354$ U.S. at 231-32.

257354 U.S. at 232. Compare Konigsberg v. State Bar, 366 U.S. 36, 52-53 (1961); Shelton v. Tucker, 364 U.S. 479, 499 (1960) (dissenting opinion).

258 Neither on grounds of scienter, as he explicitly states in Sweezy, 354 U.S. at 270 , nor in the effect on the individual of exposure in an investigation, see Watkins v. United States, 354 U.S. at 232 (by implication).

259 Konigsberg v. State Bar, 366 U.S. 36, 52-53 (1961). Three members of the Court find this distinction untenable. Id. at 72-74 (Black, J., dissenting).

260 To conclude that Congress or state legislatures might do indirectly that which they could not do directly would not be unlike the formal distinctions which resulted in unrestrained retroactive legislation in the deportation area, distinctions to which the Court seems to consider itself bound. See Galvan v. Press, 347 U.S. 522, 530-31 (1954). 
criminating answers or discoveries about associations. The specific disability cases have not yet held past unproscribed associations to be grounds for present disqualification, and it is arguable that Barenblatt has not foreclosed the issue even in investigation cases, inasmuch as the facts of Barenblatt were not unlike those of Beilan ${ }^{261}$ and Konigsberg, ${ }^{262}$ where refusal to answer all questions about past associations implied refusal to answer any questions as to present associations. ${ }^{263}$ Broad language in Barenblatt appears to do more, ${ }^{204}$ as does careless language in Konigsberg; ${ }^{265}$ but in fact the question has not yet had to be faced; such dicta should not obscure the issue which survives.

\section{ConcLusion}

While the Supreme Court has not expressly acknowledged that the first amendment prohibits retroactive government action which is likely to have a marked inhibitory effect upon the future exercise of the rights guaranteed by that amendment, the Court's decisions do display a pattern which is consistent with this thesis. Its demonstration must await the future. Meanwhile, one may hope that an analysis of the issue-believed to be an integral, if only tacit, issue in the cases-may provoke more authoritative attention.

It should be clear that if a majority of the Court intends to espouse a "balancing" test by which to determine whether freedoms of speech and association may be curtailed in order to promote certain governmental interests, there must be conscious weighing of all the elements that constitute the freedom whose restriction is thought to be necessary. Merely because a consistent minority objects to any inhibition of what they would denote the first amendment's preferred freedoms does not mean that the majority, having rejected that stand, is free to "balance" without considering when there is a change in the nature and consequences of the restraints employed.266 To say that certain instances of speech and association may be prospectively curtailed withdraws now defined areas from the first amendment's protection. But this is only a limitation; there is nullification implicit in retroactive condemnation. The inherent lack of discrimination in retroactivity cannot be remedied by current precision of

201 See text accompanying notes 177-82 supra.

262 See text accompanying notes 188-90 supra.

263 Barenblatt v. United States, 360 U.S. 109, 114 (1959) : "[P] jetitioner objected generally to the right of the Subcommittee to inquire into his 'political' and 'religious' beliefs or any 'other personal and private affairs' or 'associational activities,' upon grounds set forth in a previously prepared memorandum, which he was allowed to file with the Subcommittee." In his memorandum Barenblatt attacked the jurisdiction of the committee to ask him any questions or to conduct any inquiry at all, based on the first, ninth and tenth amendments, the prohibition against bills of attainder, and the doctrine of separation of powers. Id. at 114, n.2.

264 See note 252 supra.

265366 U.S. at 44.

266 See note 94 supro. 
statutory language, inasmuch as the hates and fears of the future may not seek catharsis in suppression of the same discordant elements as are the target of current anxieties. More is involved here than inequity. Inequity is inherent in any retroactivity. But where speech and association are concerned, the overriding consideration is the atmosphere of utter and immediate uncertainty generated by the possibility of retroactivity tomorrow, supported by precedents laid down today. No legitimate goal of democratic government can justify the blurring of what is and what is not proscribed today, and of what will be and what will not be suppressed tomorrow.

W. B.P.

M. L. S. 